AÜIFD Cilt XLIV (2003) Sayı 2 s. 131-172

\title{
Bir Belgeye Göre Amasya II. Bayezid Külliyesi
}

\author{
Abdulkadir DÜNDAR \\ Yrd. Doç. Dr. Ankara Üniversitesi İlâhiyat Fakültesi \\ e-mail: abdulkadirdundar@yahoo.com.
}

Abstract: According To A Document The Kulliyah Of Amasya Bayezzd II. In this paper, It is evaluated that an archival document which is found in Topkapi Palace Museum Archives. Monuments which make up the Kulliyah of Bayezid II in Amasva province are inroduced. The document which is not known by whom it was written and by which purpose had been written after the completion of kulliyah in 1486. In this document, very important and orijinal informations are given about the montments of Kulliyah which is surrounded by enclosures. In this paper, these informations are evaluated by comparing which other sources and monuments in these present conditions. Thus, this paper is concluded by suggesting the monumentns which are consisting of the Kulliyah of Amasya Bayezid II and the orijinal style of courtyard.

Key words: Kulliyah, courtyard, mosque, madrasah, imarah, an archival document, monuments.

\section{Giriş}

Osmanlı Mimarisi'nde yapıların, inşaat organizasyonu ve bu organizasyonda görev alanlar, malzemenin temini, çeşitli harcamalar, inşaat sürecinde yapılan işlemler, bakım, onarım ve tamirleriyle ilgili olarak, 
önemli bilgiler ihtiva eden pek çok belge ve defter bulunduğu halde, mimarî eserlerin tasarımlarını konu edinen ve yapımları tamamlandıktan sonra tasvirli anlatımlarını içeren özgün yazılı kaynaklar yok denecek kadar azdır. Bu bakımdan yapıların inşâ edildikleri dönemlere ait orijinal yazılı belgelerin tespit edilip, özellikle de mevcut durumlanyla karşılaştırılarak değerlendirilmesi önemli bir çalışma alanıdır.'

Topkapı Sarayı Müzesi Arşivi’nde 1997 yılında tespit ettiğimiz Amasya II. Bayezid Külliyesi'ne ait yapıların tanıtıldığı belge, hem külliyeyi oluşturan yapıların özgün durumlarını ortaya koyması hem de yukarıda bahsettiğimiz araştırma alanına sağlayacağı katkı bakımından oldukça önem taşımaktadır. Belge Topkapı Sarayı Müzesi Arşivi'nde "D. 10232" numaralı fişte kayıtlıdır. Üç sayfadan oluşan belgenin kağıtları büyük ebatlıdır. Aynı zamanda bu kağıtlar, parmakları hafif kapalı sol el ve bu elin orta parmağının ucundan çıkan çizginin üzerine yerleştirilmiş beş kollu taç* filigranlıdır. ${ }^{2}$

Belge harekeli nesih hatıyla yazılmıştır. İlk iki sayfadaki yazılar iki sütun hâlinde olup, son sayfa ise tek sütunludur. Belğenin hangi amaçla ve kimin tarafından yazıldığıyla ilgili olarak bir bilgi bulunmamaktadır. Ayrıca belgede her hangi bir tarih de yoktur. Ancak yukarıda belirttiğimiz kayıt fişinde belgenin 15. yüzyılın sonlarına ait olduğu belirtilmektedir. Yukarıda değindiğimiz filigranın benzerlerinin 15 . yüzyılın son çeyreğine ait olması ${ }^{3}$ ve bugün külliye içerisinde yer alan 1513 yılında inşa edilmiş olan Şehzade Osman Türbesi ${ }^{4}$ ile ilgili olarak belgede hiçbir bilgi verilmemesi, belgenin fişinde belirtilen tarihi destekleyen önemli deliller sayılabilir. Dolayısıyla bütün bunlara dayanarak belgenin 15 . yüzyılın sonlarına ait olduğunu söyleyebiliriz.

Belgenin Arap harfleriyle Osmanlıca yazıh orijinal nüshasını ve bu nüshanın transkripsiyon kurallarına uygun olarak çevirisini**, yapıların plânlarını ve bu yapıların 1952 yılından önceki ve bugünkü durumlarını gösteren 26 resmi makalenin sonuna ekledik. Bu çeviriden cümleler veya pasajlar alarak metin içerisinde, diğer başka kaynaklardan elde edilen

1 Bkz. Doğan Kuban. "Tarih-i Cami-i Şerif-i Nur-u Osmani ve XVIII. Yüzyıl Osmanlı Yapı Tekniği Üycrine Gözlemler", Tirk ve Islâm Sunan Üzerine Denemeler, İstanbul 1995. s.142.

*: Belgedeki bu filigranı çizerek fax ilc bize gönderen Topkapı Sarayı Müzesi Müdürü Sayın Ülkü Altındağ’a teşekkür ederiz.

2 Filigranlar hakkında geniş bilgi için bkz. C. M. Brıquet. Les Filıgranes, I. II, III, IV, (Edıted by: Allan Stevenson), Amsterdam. Holland-1968. El filigranlarının anlatımları için aynı eserin II. cildi s.544-585' c şekilleri için ise IV. ciltteki 10630'dan $11667^{\prime}$ ye kadar olan numaralara bakınız.

"Bkz. Brıquet, a.g.c.. IV. cilt, şekil no: 11323, II. cilt, s.572.

4 Bkz. Abdi-zâde Hüseyin Hüsameddin. Amasya Tarihi, Cilt: 1. (Sad. Ali Yılmaz-Mehmet Akkuş). Ankara 1986, s.168; 1. Aydın Yüksel, Osmanlı Mimarisinde /1. Bayczid Yavız. Selim Devri (886-926/1481-1520). V, 1. Baskı, ìstanbul 1983, şekil: 12.s. 29.421. 
bilgiler ve külliyeyi oluşturan yapıların bugünkü durumlarıyla karşılaştırarak değerlendirdik. Belgede geçen, fakat sözlüklerde haklarında bilgi bulamadığımız bazı terimleri, belgenin genel yapısı ve o terimlerle ilgili verilen bilgiler ışığında açıkladığımızı da burada belirtelim.

Osmanlı mimarisinde kuruluş dönemi külliyeleri, belirli bir eksen düzeni olmadan dağ̆ınık olarak inşa edilen yapıları ile Anadolu Selçuklu ve Anadolu Beylikleri külliyelerinin bitişik düzenli kuruluşundan farklıdır. ${ }^{5}$ İstanbul'un fethinden Mimar Sinan dönemine kadar geçen süre içerisinde inşa edilen külliyeler ise genellikle belirli eksen üzerine yerleştirilen yapılarıyla düzenli bir kuruluşa sahiptir. Bu dönemde câmi , külliyelerin ana yapısı olarak karşımıza çıkar ve orta ekseni belirler. Câmiin iki yanında ise bu eksene paralel olarak uzanan yan eksenler üzerindeki diğer yapılar yer alır. ${ }^{6}$ Dört taraftan ihâta duvarlariyla çevrili olan ve 1486 yılında inşası tamamlanan Amasya II. Bayezid Külliyesi, yapılarının uygun ve düzenli dağılımı ile döneminin önemli külliyeleri içerisinde yer almaktadır.? Külliye yapılarının bu belirli bir eksen üzerinde düzenli kuruluş ve dağglımları, aşağıda detaylı bir şekilde inceleyeceğimiz belgede "Ve medresenüñ ve 'imâretüñ̃ ve maṭbahuñ öñî ve ardı beraberdür. Şöyle ki, ip dutulsa bir barmak ziyâde yâ eksük olmamışdur." şeklinde ifade edilmektedir. (Şekil: 1)

Belgenin başında "Bu tafsîl Amasiyye'de olan 'imâretüñ ve medresenüñ binâların beyân ider ki" şeklinde zikredilen bilgiden Amasya II. Bayezid Külliyesi'nin medrese ve imaretten oluştuğu anlaşılmaktadır. Ancak burada, imaret kavramıla hangi yapıların kasdedildiği açık olmamakla birlikte, belgede haklarında bilgi verilen yapılar göz önünde bulundurulduğunda, genel olarak imaretle câmi ve beş bölümden oluşan imaret binasının belirtildiğini söyleyebiliriz. Fakat şunu da zikredelim ki, külliyenin vakfiyesinde "imaret-i âmire" şeklinde belirtilen yapı, yukarıda bahsedilenin dışında imaret olarak tavsif edilmeyip bu kavramla daha ziyade câmi kasdedilmektedir. Zaten imaret kavramının, genel olarak külliyeler yerine, birden fazla fonksiyonlu tabhaneli câmiler yerine ve crken dönem

** Orijinal metnin trankripsiyonunun yapılmasında yardımcı olan Prof. Dr. Mehmet Akkuş ve Yrd. Doç. Dr. Zülfíkâr Güngörr'e teşekkür ederiz.

5 Bkz. Tanju Cantay, "Osmanlı Devletinin Kuruluşundan İstanbul'un Fethine Kadar Osmanh Sanatı”. Mimarbası Koca Sinan Yaşadığı Çă̆ ve Eserleri. (Ed. Sadi Bayram). C. 1, İstanbul 1988, s.57-58

"Bkz. Tanju Cantay, "Fetih'ten Sonra, Mimar Sinan'a Kadar Osmanlı Sanatı", Mimarbaşı Koca Sinan Yaşadığı Çă̆ ve Eserleri, (Ed. Sadi Bayram). C. I, İstanbul 1988. s.75-76.

7 Bkz. I. Aydın Yüksel, a.g.c., s.15. şekil. 7; Cantay. "Fetih'ten Sonra, Mimar Sinan'a Kadar Osmanlı Sanatı", s.76; Oktay Aslanapa, Osmanlı Mimarisi, İstanbul 1986, s.122-125. 
Osmanlı kitâbelerinde de belirtildiği gibi ${ }^{8}$ tek bir yapı yerine gibi, farklı şekillerde kullanıldığı bilinmektedir. ${ }^{y}$

Amasya'da II. Bayezid Vakfi'na ait Cemaziyelevvel 901/Ocak 1496 tarihli vakfiyedeki bilgilere göre Amasya II. Bayezid Külliyesi, imâret-i âmire, câmi, medrese ve mektepten oluşmaktadır." Ancak vakfiyede mekteple ilgili "Yine bu şehirde imâretin yakınında vadinin şark tarafında şerefli bir bina yapnıştır ki bu sıbyan mektebi olacaktır. Çocuklar orada Kur'ân-1 kerîm öğrenecektir" şeklinde geçen bilgilerden mektebin ihâta duvarlarıyla çevrili imâret-i âmire, câmi ve medresenin dışında kaldığı anlaşılmaktadır." Abdi-zâde Hüseyin Hüsameddin ise bu mektebin Bayezid Câmii'nin doğu tarafında bulunan imarethanenin hizasındaki köşe başında bulunduğunu, Sultan II. Bayezid tarafından 890/1485 yılında yaptırıldığını ve 1300/1883 yllında İbtidâî Mektebi'ne dönüştürüldüğünü zikretmektedir. ${ }^{12}$

Belgede zikredilme sırasına göre Amasya II. Bayezid Külliyesi şu yapılardan kurulmuştu: Câmi (imaret), câmiin önündeki Büyük Şadırvan, Medrese, Mut'imehâne(yemekhane), Matbah, Kilâr, Fırın, Ahır, ahırın önündeki Çeşme, mutimehâne önündeki Şadırvan, Muallimhânenin Tabhânesi, matbah arkasındaki İki Ev ve İki Anbar ile dört hücreli Helâ. Günümüze ulaşamayan ve yukarıda hakkında bilgi verdiğimiz mektep ile ilgili olarak belgede hiçbir bilgi verilmemektedir. Büyük bir ihtimalle bunun sebebi mektebin, dört taraftan da ihâta duvarlarıyla çevrili avlunun dışında

"İmaret kavramının erken dönem Osmanlı yapı kitâbelerindeki değişik kullanımları ve örnekleri iç̧n bkz.Abdülhamit Tüfekçioğlu. Erken Dönem Osmanlı Mimarisinde Yaz,ı, Ankara 2001.

9 Imaretin farklı anlamları ve imaretlerle ilgili geniş bilgi için bkz. Metin Sözen-Uğur Tanyeli. Sanat Kavram ve Terimleri Sözliuğü, İstanbul 1992, s.112-113; Doğan Hasol, Ansiklopedik Mimarlık Sözlüğ̈, İstanbui 1993, s. 214-215; Celâl Esad Arseven, "İmâret", Sanat Ansiklopedisi. II.. İstanbul 1947. s. 774-775: Cl. Huart, "İmâret". Islâm Ansiklopedisi, V/II.. Eskişehir 1997, s. 985; M. Zeki Pakalın, Osmanlı Tarih Deyimleri ve Terimleri Sözluğü II, (2. baskı), İstanbul 1971, s. 61-63; Aptullah Kuran, "Şam Sülcymaniyc Külliycsi”, Mimar Sinan Dönemi Türk Mimarlı̆ğ ve Sanan, (Yay. Haz. Zcki Sönmez), İstanbul 1988. s.169; Başbakanlık Osmanlı Arşivi(BOA), Kamil Kepeci(KK), nr. 62, s. 60; Abdulkadir Dündar, "XVI. Yüzyıl Bazı Osmanlı Minarları", Ankara Üniversitesi Mlahivat Fakiullesi Dergisi, Cilt: XLIII, Ankara 2002. s.240): Osman Nuri Ergin, Tükiye'de Şehirciliğin Tarihì Inkişafl, İstanbul 1936. s.34-45, Türk Şehirlerinde imaret Sistemi, İstanbul 1939, s. 5-19; İ. Aydın Yüksel. "İmâretler". II. Vakıf Hafıası, 3-9 Aralık 1984. Ankara 1985. s. 163-167; M. Baha Tanman, "Sinan Mimânisi İmâretler", Mimarbaşı Koca Sinan Yaşadı̆̆ı Çă̆ ve Eserleri l., İstanbul 1988, s. 333-353; Tülay Reyhanlı, "Osmanlı Mimarisinde İmâret: Külliye Uzerine Notlar", Türk Kültürï Araşıtrmaları, XV/1-2. 19751976, s.121-141.

11 Vakıflar Genel Müdürlüğü Arşivi'ndeki bu vakfiyenin orijinal nüshası Kasa Defteri: 60, sayfa: 52, sıra: $119^{\prime}$ dadır. Vakfiyenin Arapça sureti isc: 2113 no'lu defterin 32. sırasında 179. sayfasındadır. Türkçesi ise 2148 No lu defterin 84-113. sayfalarındadır.

"Bkz. Adı geçen vakfiycnin Türkçe tercümesi 2113 no'lu defter, s.87-88.

1: Abdi-Lâde Hüseyin Hüsameddin, a.g.e., s.213. 
olmasıdır. Zaten belgede, Amasya'da Il. Bayezid döneminde inşa edilen diğer yapılarla ilgili hiç bir bilgi verilmeyerek, belgedeki bilgilerin sadece avluda bulunan yapılarla alakalı olması bunu teyit etnıcktedir. Şimdi belgede zikredilen sıralarına göre Amasya II. Bayezid Külliyesi'ni oluşturan yapıların ve bu yapılar hakkında verilen bilgilerin değerlendirilmesine geçebiliriz.

\section{Câmi}

Belgede külliyenin anlatımına câmi ile başlanmıştır. Külliyenin merkezî yapısı olan câmiin iki büyük kubbeli olduğgu belirtilerek, bu kubbeler ön ve arka olarak tarif edilmektedir.(Şekil:2) Buna göre öndeki büyük kubbe mihrap önündeki, diğeri ise bunun arkasındaki ikinci kubbedir. ${ }^{13}$ Arkadaki kubbe mihrap önündekine göre daha küçük olduğu hâlde bu husus belgede belirtilmemiştir.(Fotoğraf:1) Amasya'da 1591, 1668-1669'14, 1939 ve 1943 yıllarında depremler ${ }^{15}$ olmuş ve bu depremlerden son ikisinde câmiin kubbeleri büyük hasar görmüşstür. Bu nedenle, vesikada belirtilen kubbeler günümüze, bu depremlerden sonra yapılan onarımlarla ulaşmıştır. ${ }^{16}$ Belgede bu iki kubbe ortasındaki kemere değinilcrek, kalınlığ üç zira ${ }^{17}$ (yaklaşı 2. $27 \mathrm{~m}$.) olarak verilmektedir. Gabriel bu kemerin kalınlığını $1.41 \mathrm{~m}$. verirken ${ }^{18}$ Aydın Yüksel $2.37 \mathrm{~m}$. olarak vermektedir. ${ }^{19}$ Böylece kemerin kalınlığı hakkında verilen ölçü, Gabricl'inkiyle aralarında büyük fark varken Yüksel'inkine yakındır. Bugünkü duruma göre, doğru olan Aydın Yüksel'in vermiş olduğu ölçüdür. Kemerin içinde asılı olduğu belirtilen çift bir şcyden bahsedilmektedir ki muhtemelen bu çift kandildir. Bugün bu kandiller mevcut değildir. Büyük bir ihtimalle bunun sebebi, 1939 yllındaki depremde bu kemerin çökmesinden sonra yapılan onarımlarda tekrar yerlerine konmamalarıdır. (Fotoğraf:2)

${ }^{13}$ Bkz.Yüksel, a.g.e., s. 20.

14 Bk7. Abdi-7âde Hüseyin Hüsameddin, a.g.e., s. 105-106; Yükscl. a.g.e., s.23; Besim Darkot. "Amasya", Islâm Ansiklopedisi. İstanbul 1950, s.395-396.

${ }^{15}$ Kuzey Anadolu fay hattında meydana gelen 1939 yılındaki deprem 8.0 şiddetinde olup merkez üssü Erzincan'dır. Aynı hattaki 1943 depremi isc Corum'da 7.2 şiddetinde olmuştur (bk\%.Anaßrirannica. Cilt: 7. İstanbul 1987, s.156).

16 1952-1971 yılları arasında gerçekleştirilen onarımlar hakkında Bkz.Vakıflar Genel Müdürlüğü Abide ve Yapı İşleri Dairesi Arşivi Amasya II. Bayezid Külliyesi Dosya no:05.01.01/2; Cumhuriyerin 50. Yilmada Vakiflar. Ankara 1973. s.18.

${ }^{17}$ Osmanlılar döneminde bir zira' genellikle $0.758 \mathrm{~m}$. olarak kabul edilmektedir. Geniş bilgi için bkz. Feza Günergun. "Osmanlılar ve Metre Sistemi". Osmanl, 8. (Editörler: Güler Eren. Kemal Çiçck ve Cem Oğuz), Ankara 1999. s.655-663; "Osmanh Ölçü ve Tartılarının Eski Fransiz ve Metre Sistemlerindeki Eşdeğerleri: İlk Karşılaştırmalar ve Çevirme Cetvelleri”. Osmamlı Bilimi Arasstımalar II. (Yay. Haz. Feza Günergun), Istanbul 1998, s. 23-68.

${ }^{18}$ Bkz. Albert Gabricl. Monuments Tures D' Anatolec Amusya -Tokat-Sivas. Cilt: II. Paris 1934, s.34

19. Bkz. Yüksci.a.g.e..s. 16. 20. Şekil: 8. 
Öndeki kubbenin koltuklarının mukarnashı ve işlemeli, arkadakinin ise sâde yani mukarnassız olduğu ve birer şemse ${ }^{20}$ yazıldı ̆̆ belirtilmektedir. Ayrıca bu kubbenin ortasındaki, etrafı bezemeli büyük bir şemseden ve bu şemsenin de ortasındaki "müsenna hat" vuḍ 'a" 22 âyetinden bahsedilmektedir. Şemseler ve şemselerin etrafındaki bezemeler ve anlatılan diğer süslemeler döneminin kalem işleri olmalıdır. (Fotoğraf:3) Yukarıda belirttiğimiz depremler ve yapılan onarımlar nedeniyle, belirtilen bu süslemeler, müsenna hatlı yazılar ve ön kubbenin mukarnaslı geçiş unsurları, günümüze ulaşmamış olup, câmide görülen bugünkü bitkisel motif ağırlıklı kompozisyonlardan oluşan kalem işleri ise son dönemlere aittir.

Gerideki kubbenin ortasında da bir şemse olduğu zikredilerek, şemsenin ortasının tezyinatlı, etrafında ise müsenna hat ile "İnnemâ ya'muru mesâcida'llâhi..." âyetinin yazılı olduğu belirtilmektedir. Böylece her iki kubbenin ortasında da şemse olarak adlandirılan ve farklı kompozisyonlardan oluşan bezemeli birer göbeğin bulunduğu anlaşılmaktadır. Ayrıca belirtilen yazılar, ön kubbedeki göbeğin ortasına, arkadakinin ise çevresine yerleştirilmiştir. Belgede, kubbelerle ilgili verilen bilgilerde, daha ziyade yukarıda değindiğimiz gibi, kubbelerdeki kalem işi süslemelerine ağırlık verilmiştir. Kubbeye geçiş unsurları "kubbe koltukları" şeklinde genel bir ifade ile belirtilmiş olmasına rağmen, mihrap önündeki kubbenin içi işlemeli mukarnaslarla doldurulmuş tromplu, arkadakinin ise şemse motifli kalem işlẹi tezyinatlı muhtemelen pandandifli olduğu anlaşılmaktadır. Bugün her iki kubbenin geçiş unsurları da trompludur. (Fotoğraf: 4)

Kubbelerdeki bu kalem işlerinden başka, ön kubbenin örttüğü mekânın duvarlarında dört, gerideki kubbenin örttüğü mekânın duvarlarında ise büyük iki şemseden bahsedilmektedir ki, bugün bunlar da mevcut değildir. (Fotoğraf:5) Halbuki 1952 yılından önce çekilmiş resimlerden, câmiin içinde bugünkünden çok farklı kalem işlerinin mevcut olduğu anlaşılmaktadır. (Fotoğraf:6)

\footnotetext{
${ }^{*}$ Şemse bir daire ile ondan yayılan ışınsal çizgilerden oluşan güneş biçimindcki bezemedir. Ayrıca, tezhip sanatı ile Osmanlı deri cilt kapaklarının dışında yeralan, tezyinatlı. iki ucu sivri, cliptik biçiminde ve madalyona benzer örgelere de şemse denir (Bkz. Sözen-Üğur Tanyeli, a.g.c, s.226. Hasol, a.g.c, s.427-428).

${ }^{21}$ Aynalı yazı olarak da bilinen müsenna hat, genellikle celî sülüs yazı türünde sağ taraftaki cümlenin sol tarafta da ters yansıtılarak meydana getirilen kompozisyon veya istif biçimine denilmektedir (Bkz. Tüfekçioğlu. a.g.e., s.501; Muammer Ülker, Başlangı̧̧tan Günümüze Türk Hat Sanatı. Ankara 1987, s.13).

22 Al-i İmrân Sûresi âyet: 96 "Doğrusu insanlar için ilk kurulan ev, Mekke'de, dünyalar içín mübârck ve doğru yol gösteren Kâbe'dir"

23 Tevbe Sûresi âyet 18: "Allah'ın mescidlcrini sadecc. Allah'a ve âhiret gününe inanan namaz kılan. zekât veren ve ancak Allah'tan korkan kimseler onarır."
} 
"Kemerlere țaş mevc ${ }^{24}$ tarḥ ${ }^{25}$ olmışdur" ifadesiyle kemerleri oluşturan taşların birbirine zıvanalı geçmeler şeklinde bağlı olduğu belirtilirken ${ }^{26}$, kemerlerin çeşitleri hakkında bilgi verilmemektedir. Ayrıca bu kemerlerin hangi kemerler olduğu açık bir şekilde belirtilmemiştir. Fakat, kemerlerle ilgili bu açıklamanın belgede, kubbelerin ve pencerelerin anlatıldığı bölümde yer alması, bu kemerlerin kubbeye geçiş unsuru olan trompların önündeki kemerler ile yanlardaki sathî kemerler veya pencerelerin kemerleri olabileceğini düşündürmektedir.

Belgede, "Ve yigirmi bir mukattạa" ve vezirîn ${ }^{27}$ câm pencereler olmışdur." ifadesinden kasdedilen, her iki kubbenin kasnakları dışında, mihrap önü mekânı ile arkadaki mekânın vitraylı pencereleri olabilir. Bugün bunların toplam sayısı yirmi bir değil yirmi altıdır. Bu pencerelerin on altı tanesi mihrap önü mekanında, ikisi arka kubbenin altında, dörder tanesi ise yan kanatlardadır. Buradaki "vezirî câm" teriminden vitraylı ve dikdörtgen şekilli pencerelerin kasdedildiğini anlıyoruz. Pencerelerin şekilleri belirtildiği halde, kemerlerin ve kubbelerin biçimlerine hiç değinilmemiştir. Ayrıca, büyük iki kubbenin sekizgen kasnaklarının her bir kenarında ikişer olmak üzere yer alan, toplam on altışar pencereden ise hiç bahsedilmemektedir.

Vitraylı bu pencereler dışında belgede, "muḳațta' ḳâpûlu" on pencereye daha değinilmektedir. "Muḳața' kâpûlu" şeklinde ifade edilen pencereler ahşap kanatlı pencereler olmalıdır ${ }^{29}$ Bugün câmide toplam 20 adet ahşap kanatlı pencere bulunduğu hâlde, belgede sadece mihrap önü mekânındakiler

${ }^{24}$ Mevc: Dalga

${ }^{2}$ Arapça tarh şeklinde okunan bu kelime Farş̧a terh olarak okunmakta olup şu anlamlara gelmektedir: Plân. tasarım, proje, yol, iz, atma, koyma, bırakma, tertib, tanzim, açma, yayma (Bkz. Şemseddin Sami. Kâmûs-i Türkî, İstanbul 1317. s.880; Mehmet Kanar, Farsça-Türkçe Sözlük. İstanbul 2000, s. 767)

${ }^{26}$ Osmanlı dönemi kemerlerinde uygulanan zıvanalı geçmeler hakkında bilgi için bkz. Celal Esad Arseven, Türk Sanan Tarihi, Menşeinden Bugüne Kadar Mimari, Heykel, Resim, Siisleme ve Tezyini Sanatar. İstanbul (Tarihsiz), s.689-695.

${ }^{27}$ Mukatta': Kesilmiş. kesik, ayrı, parça.

28 Vezin̂ kelimesinin sözlüklerde iki anlamından bahsedilmektedir. Birincisi vezire mensub yaşayan ve olan şeyler, ikincisi ise mustatîl hacimde yani dikdörtgen şeklinde olan şeyler (Bkz. Şemseddin Sami, a.g.e.. s.1491; Ferit Develioğlu, Osmanlıca-Türķ̧e Ansiklopedik Lûgat, Ankara 1988, s.823). Burada konumuz açısından "Vcziri câm pencereler" den, dikdörtgen şeklinde camlı yani vitraylı pencerelerin kasdedildiği anlaşılmaktadır.

${ }^{20}$ Osmanlı dönemi ahşap iş̧̧iliği hakkında bkz. Rüstem Bozer, Erken Osmanlı Dönemi Ahşap

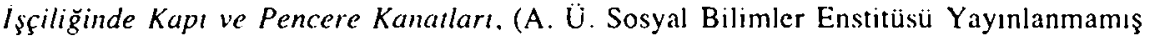
Yüksck Lisans Tezi), Ankara 1986; Aynı yazar. "Sinan Escricrinde Ahşap İş̧̧iliği", VI. Vakıf Haftast, İstanbul 1989, s.327-346; N. Sinemoğlu, "Üsküdar Mihrimah Câmii (İskele Câmii) Ana Giriş Kapısı Kanatları”, Akademi 10, Mimarlık ve Sanat, İstanbul 1981, s.41. 46. 
belirtilmiştir. Halbuki câmiin doğu ve batı kanatlarında üçer, kuzey cephede ise dört olmak üzere ahşap kanatlı on pencere daha vardır. ${ }^{30}$

Câmideki kapılarla ilgili olarak belgede "Ve iki kâpû dạ̣i șuffelere açılur. İç yüzlerine mukatța' kâpûlar aşılmışdur. Ve țaş yüzlerine demürden düvâzde ${ }^{31}$ çenber-girih ${ }^{32}$ ḳâpûlar işlenmişdür, açılur, yapılur. Ve câmi'üñ büyük kâpûsı" şeklinde geçen bilgilerden, câmide ahşap kanatlı, bir büyük, iki de küçük üç kapının bulunduğu ve bu kapılardan ikisinin dış taraflarında, yani bugünkü muşamba perdelerin yerine, on iki yuvarlak rozetli ve demirden yapılmış dış kapıların olduğu anlaşılmaktadır. Bu üç orijinal kapıdan günümüze sadece, kuzeydeki son cemaat yerinden câmiin arka mekânına açılan büyük kapı ulaşmış olup ${ }^{33}$, doğu ve batıdan yan kanatlara açılan diğer iki kapıdan ise hiçbir şey kalmamışır. Bu üç kapının da camiye açılan cephelerinin önünde yer alan bölümlerin "suffe" olarak adlandırılması, dönemin suffe kavramına önemli bir açıklık getirirken; Anadolu Türk evlerinde odaların açıldığı geniş mekânların ve odalar arası ortak bir alanın "sofa" olarak adlandırılmasının espirisini de ortaya koymaktadır..$^{35}$

Belgede "Ve câmi'üñ büyük kâpûsınuñ iç yüzinde üzerinde demür muhaccerlü̈ bir șuffe olmışdur." şeklinde verilen bilgilerle, cümle kapısının sağ ve solundan duvar içinden iki merdivenle çııılan ve yaklaşık $1.30 \mathrm{~m}$. genişliğindeki mahfii ${ }^{37}$ tanıtılmaktadır. Buna göre taş konsollar üzerine binen bu mahfilin demir korkuluklu olduğu anlaşılmaktadır. Sekizer köşeli beş siyah mermer sütuna binen ve aynı zamanda batı tarafı, mihrap önü mekânın kuzeybatısındaki ayağa dayanan, ahşap korkuluklu, oldukça sâde ve yerden 2. $50 \mathrm{~m}$. yükseklikteki müezzin mahfili ${ }^{38}$ (Fotoğraf:7) ile kuzeydeki taçkapının hemen batısındaki pencerenin son cemaat yerine bakan

\footnotetext{
${ }^{30}$ Bu pencercler hakkında geniş bilgi için bkz. Yüksel, a. g. e., s. 25-26.

${ }^{31}$ Düvâzde: Oniki

${ }^{32}$ Girih sözluklerde düğüm, boğum, budak, kilit, kırışı ve eski bir uzunluk ölçüsü $(6.5 \mathrm{~cm}$.) olarak belirtilmektedir (bkz. Kanar, a. g.e., s. 950). Ancak, belgede bu kavramın bütün bu anlamlarının dışında büyük bir ihtimalle rozet anlamında kullanıldığı anlaşılmaktadır.

${ }^{33}$ Bu kapı geometrik geçmeli olup pirinçten döğme kuşakları vardır. Üst tablasında yazılar bulunan kapının alt tablası tamir edilmiştir (Bk\%. Yüksel, a.g.e., s.18).

${ }^{34}$ Arapça "suffe" şcklinde yazılıp telaffuz edilen ve dış kapının iki tarafında taştan veya tahtadan oturmak amacıyla kullanılan hafifçe yüksek kârgir seki anlamına gelen bu kavramın Türkçe'ye "sofa" olarak geçtiği anlaşılmaktadır (Bkz.. Şemseddin Sâmi. a. g.e., s. 828; Sözen, a.g.e., s. 217-218)

${ }^{35}$ Bkz. Önder Küçükerman-Şemsi Güner. Anadolu Mirasında Türk Evleri, İstanbul 1995, s. 179, 183; Reha Günay, Türk Ev Geleneği ve Sufranbolu Evleri, İstanbul 1998, s. 142; Komisyon, Mersin Evleri, Ankara 1995, s. 56-121.

3uhaccer Arapça bir kelime olup, taş korkuluk. taşlaşmış, hâle ve yasak antamları dışında (bkz.Kanar, a.g.e., s. 1040). türbelerde sandukayı çevrcieyen mermerden oyulmuş kafeslere de denmektedir (bkz.Sözen-Tanyeli, a.g.e., s.166).

${ }^{37} \mathrm{Bkz}$. Yüksel, a.g.e., s. 20.

${ }^{3 k}$ Bkz. Yüksel, a.g.e., s. 20.
} 
cephesinin üstünde yer alan mükebbire ${ }^{39}$ hakkında belgede hiçbir bilgi verilmemektedir. (Fotoğraf:8)

Câmiin ebatları belgede şu şekilde verilmektedir: "Ve câmi' içinüñ țûlı kırk iki zirâ'dur. Ve arẓı yigirmi bir zirâ'dur. Ve kaddi ${ }^{40}$ otuz üç zirâ'dur." $\mathrm{Bu}$ ölçülere göre câmiin içten içe 42 zira' ( $31.836 \mathrm{~m}$.), mihrap önü mekânının doğu-batı yönünün 21 zira' $(15.918 \mathrm{~m}$. ) ve arka mekânın ise yine doğu-batı istikâmetinde 33 zira' $\left(25.014 \mathrm{~m}\right.$.) olduğu anlaşılmaktadır. ${ }^{41}$ Görüldügüu gibi belgede verilen bu ölçüler câmiin sadece iç ebatlarıyla ilgili olup, dış ölçüleri hakkında herhangi bir bilgi verilmemektedir. İ. Aydın Yüksel câmiin içten içe 30.53 x $29.97 \mathrm{~m}$. diştan dişa $45.44 \times 42.95 \mathrm{~m}$., mihrap önü mekânının ise doğu batı yönünde $15.16 \mathrm{~m}$. olduğunu belirtmektedir. ${ }^{42}$ Belgede verilen bu ölçülerle, câmiin bugünkü belirtilen ölçüleri arasında genel olarak çok önemli bir farkın olmadığı görülmekle birlikte, arka bölümün doğu-batı istikâmetinde verilen ölçüler arasında yaklaşık $5 \mathrm{~m}$. gibi bir fark vardır. Belgede son cemaat yerinin anlatıldı̆̆ı bölümde "Ve 'imâret dîvârınuñ kalıñı üç zirâ'dur." denilerek câmiin duvarlarının kalınlığı da verilmiştir. Üç zira' yaklaşık 2. 27 m.'ye tekâbül etmektedir ki bu ölçü, İ. Aydın Yüksel'in vermiş olduğu duvar kalınlıklarına çok yakındır. ${ }^{43}$

Câmiin mihrap ve minberi belgede "Ve ạ̣ mermerden miḥâab işlenmişdür, muḳarnașdur. Ve minber işlenmişdür, aḳ mermerden sâde kilvekân ${ }^{44}$. Ve ḳ̂âusî dahi ak mermerdendür. Dehi ${ }^{45}$-girih ḳazılmışdur, açılur, yapılur." şeklinde anlatılmaktadır. Buna göre, ak mermer işlemeli mihrabın mukarnaslı olduğu belirtilmektedir. Belgede, mukarnasların sekiz sıralı olduğuna ve siyah-beyaz renkli, üç parçalı kum saatlerine ise değinilmemiştir. ${ }^{46}$ (Fotoğraf:9) Ak mermerden "kilvekârî" tekniğinde sâde yapılmış olan minberin, bugün mevcut olmayan yine ak mermerden kapısının bulunduğu anlaşılmaktadır. Ayrıca, "dehi girih kazılmışdur" ifadesiyle, büyük bir ihtimalle, minberdeki süslemelerden minberin batı aynalığındaki, on kenarlı, $0.64 \mathrm{~m}$. çapında, taştan ve geometrik desenlerle

\footnotetext{
${ }^{39}$ I. Aydın Yüksel müezzin balkonu olarak tarif ettiği bu mükebbirenin sonradan yapıldığını ileri sürmektedir

${ }^{40}$ Kad: Boy, endam, uzunluk, ölçü (Bkz. Kanar, a.g.e., s.861; Şemseddin Sami, a.g.e., s.1056).

${ }^{4}$ 'Burada zira' olarak verilen ölçüler, metreye çevirilirken daha öncede belirtildiği gibi 1 zira' $0.758 \mathrm{~m}$. kabul edilmiştir

${ }^{42}$ Yüksel, a.g.e., s.16, 21 .

${ }^{43}$ Bkz. Yüksel, a.g.e., s. 16, 8. şekil.

${ }^{44}$ Sözlüklerde "kilve" veya "kilvekârn̂" şeklinde herhangi bir kelime geçmemektedir. Ancak, kelimenin okunuş itibariylc "kendekâri" veya "kündekârî" ye yakın oluşu ve burada da mermer işlemeciliğinde tatbik edilen bir teknik anlam ifade ettiğinden "kilvekâri" nin büyük bir ihtimalle o dönemlerde kullanılan bir tcknik olduğunu belirtebiliriz.

${ }^{45}$ Dehi: Ongen

th Bkz. Yüksel, a.g.e., s. 20.
} 
bezeli rozet belirtilmiştir. Minberde bu rozetin dışında, korkuluğun her iki yanında, siyah ve beyaz mermerden yapılmış, $0.30 \mathrm{~m}$. çapındaki, birer kabaralı rozet ve sivri kemerli kapı alınlığında, bitkisel bezemeler ile alınlığın sağ ve sol yanlarında, kabartma sülüs yazıları da vardır. ${ }^{47}$ (Fotoğraf:10)

Belgede câmiin iç anlatımı, her kubbede üçer daire oluşturacak şekilde kandiller için yüz elli üç zincirin asılı olduğu belirtilerek bitirilmiş ve son cemaat mahalliyle ilgili şu bilgilere geçilmiştir. "Ve revişî" ${ }^{48}$ 'imâret ki, ț̂̂lı elli zirâ'dur. Ve arżı dokuz zirâ'dur. Ve altı mermer müdevver direk olmışdur. Ve başları mukarnașdur. Ve dergâh ${ }^{49}$ kubbesi penc ${ }^{50}$ kubbe muḳarnaș işlenmişdür. Ve kubbe-i mezkûrenüñ kemerleri ciftlüdür ${ }^{\mathrm{i}}$. Ve

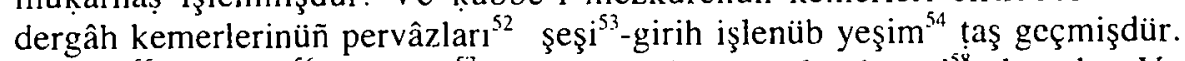
Ve nîm ${ }^{55}$ çârşûlar1 $^{56}$ müsselles ${ }^{57}$ rûmî yaprak resm olup kened ${ }^{58}$ olmışdur. Ve naḳş dâyiresine kilvedâr ${ }^{59}$ ḳızıl taş kaḥmışdur. Ve naḳş üzerinde bir kitâbe olmışdur. Bir minâreden bir minâreye varınca "İnnâ fetahnâ..." sûresi

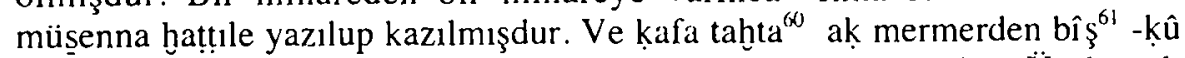
muḳarnaș işlenmişdür. Kâpû dergâhı ki, muḳarnaṣ işlenmişdür. Üç büyüuk âvizesi $^{62}$ var. Ve on sekiz küçuik âvizesi vardur."

Bu bilgilere göre, câmiin revakı olarak, 50x9 zira' yaklaşık 37. 90×6.82 ebatlarında olduğu belirtilen ve dergâh kavramıyla açıklanan son cemaat

${ }^{87}$ Bkz. Yüksel, a.g.e., s.20

4\$ Sözlüklerde gidiş, tarz, metod, geçiş, yürüyüş ve yol gibi çok çeşitli anlamlan bulunan reviş (bkz. Kanar, a.g.e., s.600; Develioğlu, a.g.e., s. 1067.), belgede revak anlamında kullanılmıştır.

${ }^{49}$ Dergâh burada bilinen tekke yapısı anlamının çok dışında son cemaat yeri manasında kullanılmıştır.

${ }^{50}$ Penc: Beş.

${ }^{51}$ Cift: Çift ve eş anlamındadır. (Bkz.Cem Dilcin, Yeni Tarama Sözlüğü, Ankara 1983, s.56).

${ }^{52}$ Kemer pervazı burada kemer alnt anlamindadır.

${ }^{5.3}$ Şeşi: Altıgen.

s4 Yeşim: Yeşb de denilen ve yağmur taşı olarak da bilinen sert ve kıymetli yeşil taş (Bkz. Şemseddin Sami. a.g.e., s.1549; Develioğlu. a.g.e., s.1396).

${ }^{5 s}$ Nîm: Yarım, yarı. buçuk.

${ }^{50}$ Çârşû: Dört tarafı.

${ }^{57}$ Müselles: Üçgen biçiminde, üç köşeli, üçlü, üç kat ve üç şeyden ibaret (Bkz. Şemseddin Sami, a.g.e., s.1289).

${ }^{58}$ Kened: Her çeşit yapım öğesini birbirine bağlayan, iki ucu kıvrık lama, demir parçası (Bkz.. Hasol, a.g.e., s.249; Sözen-Tanyeli, a.g.e., s.128).

${ }^{54}$ Kilvedâr: Muhtemelen kilvekâñ tekniğini uygulayan sanatkâr.

* Kafa tahta : Bu kavramla büyük bir ihtimalic taçkapı kavsaranının üst tarafı kasdedilmektedir.

${ }^{61}$ Bîş: Çok, fazla, misli, artık, diğer, -den fazla: Piş: ön ileri (Bkz. Semseddin Sami, a.g.e., s.366).

62 Âvîze: Küpe anlamına gelen bu kelimeyle mukarnasların u̧̧larındaki sarkıtların ifade edildiği anlaşılmaktadır. 
yeri, bugünkü gibi altı yuvarlak sütunlu olup sütun başlıkları da mukarnaslıdır. Verilen bu ölçülerle, İ. Aydın Yüksel'in belirttiği $38.85 \times 7$. 26 m.'lik ölçüler arasında fazla bir farkın olmadığı görülmektedir. ${ }^{63}$ Belirtildiği gibi son cemaat yeri beş kubbeyle örtülüdür. Kubbelerde olduğu zikredilen mukarnaslar ise bugün mevcut değildir. Çünkü son cemaat yeri 1939 depreminde tamamen çökmüş olup, 1952-1971 yılları arasındaki onarımlarda tamamen yenilenmiştir. (Fotoğraf:11) Kubbelerin çifte kemerlerinden neyin kasdedildiğini belirleyemedik. Ancak, muhtemelen burada anlatılmak istenilen şcy, kubbelerin dışa bakan kemer alınlarını boydan boya dolaşan ve "dergâh kemerlerinin pervazlanı şeşi girih işlenüp" cümlesiyle açıklanan, altıgenlerle oluşan tezyinî kuşak olabilir. Kemer alınlarının etrafını boydan boya dolaşan bugünkü ince firizin bu tezyinî kuşağın hatırasını taşıyor olması kuvvetle muhtemeldir. (Fotoğraf:12) Kemerler bugün kırmızı, beyaz ve gri mermerli olup, belirtilen yeşim taş, sadece cümle kapısının gömme sütuncelerinde bulunmaktadır. Kened tekniğiyle sağlamlaştırıldığı vurgulanan ve "nîm çârşûları" şeklinde ifade edilen kemer kamaları ile kamalarda bugün mevcut olmayan rûmî yapraklardan bahsedilmektedir. Üzerinde yazı, ortasında ise kakma tekniğinde kızıl taş bulunduğu zikredilen bezemeli dairenin, son cemaat yerinin neresinde olduğu belirtilmemektedir. Bir minareden diğerine kadar, müsenna hat ile kazılı olduğu bahsedilen Fetih sûresinden günümüze hiçbir şey ulaşmamıştır. Ak mermerden bol mukarnas işlemeli olduğu belirtilen, taçkapı kavsarasının üst tarafı "kafa tahta" olarak, mukarnasların uçlarındaki bugün de mevcut olan sarkıtlar ise ebatlarına göre "büyük, küçük âvize" şeklinde nitelendirilmektedir. Mukarnasların üçünün büyük, on sekizinin ise küçük sarkıtlı olduğu zikredilmektedir. ${ }^{64}$ (Fotoğraf: 13,14 )

Belgede, içten içe $8 \times 8$ zira' yaklaşı $6.064 \mathrm{~m}$. ebatlarında dört tabhane ve bunların önünde birer olmak üzere, $9 \times 9$ zirâ yaklaşık $6.822 \mathrm{~m}$. ölçülerinde iki suffedan bahsedilmektedir. Böylece câmiin arka bölümünün doğu ve batı kanatlarında yer alan kısmın, kapıların açıldığı ortadaki mekânlar suffe, her iki kanadın bu bölümünün güney ve kuzeyindeki kısımlar ise tabhane olarak belirtilmektedir. ${ }^{65} \mathrm{Bu}$ açıklamalardan, büyük kubbeyle örtülü, mihrap ve minberin bulunduğu bölümün câmi, bunun arkasındaki bölümün bir nevi avlu fonksiyonu gören başka bir mekân, bu mekânın doğu ve batısında yer alan bölümlerin ortasının suffe, güney ve kuzeylerinin ise tabhane olduğu sonucu çıkmaktadır. Zaten bütünüyle yapı, belgenin hiçbir yerinde câmi olarak nitelendirilmeyip, yapının tamamını bir

${ }^{63}$ Bkz.Yüksel a.g.e., s.18.

${ }^{4}$ Bu taçkapının erken dönem Osmanlı mimanisindeki diğ̣er taçkapılarla karşılaştırılması konusunda geniş bilgi için bkı.Şakir Çakmak, Erken Dönem Osmanlı Mimarîsinde Taşkapılar (1300-1500), Ankara 2001, s.15, 23, 40, 44, 77, 87, 89, 174, şekil:32. 58, 59, profil:56.

"s Tabhaneli câmiler hakkında geniş bilgi için bkz. Semâvî Eyici, "Zâviyeler ve Zâviyeli Câmiler”, I. U. Iktisat Fakultesi Mecmuast. Cilt: 23, İstanbul 1962-1963, s.3-80. 
kavramla anlatmak gerektirdiğinde ısrarla "imaret" kavramı kullanılmıştır. Belgede bu tabhanelerin, gerek ortalarındaki sofalara açılan cephelerinin gerekse ön ve arka kubbenin örttüğü mekâna açılan cephelerinin bugünkü gibi açık veya kapalı olup olmadıklarıyla ilgili herhangi bir bilgi verilmemektedir. Dolayısıyla mevcut bilgilerle, belgede tabhane olarak tanıtılan bu mekânların, belirttiğimiz cephelerinin kapalı olduklarını ileri sürmek mümkün görülmemekle birlikte yapılacak sondajlarla bu şüpheler giderilebilir. Ayrıca, tabhane olarak kullanılan dörder odaya sahip olmaları bakımından buna çok benzeyen Bursa Yıldırım (1395) ve Afyon Gedik Ahmet Paşa (1472 yılı dolayları) câmilerinin yan kanatlarındaki bu tabhane odaları iç tarafa, Gedik Ahmet Paşa'da pencereyle, Bursa Yıldırım'da ise kapıyla bağlanmıştır. ${ }^{67}$

Câmiin, belgede "Biri kule ve biri şânizdeh ${ }^{68}$ duțuğnukdur." cümlesiyle anlatılan iki minaresi vardır.(Fotoğraf:15) Bu cümle ile muhtemelen minarelerden birinin gövdesinin kule şeklinde, diğerinin ise onaltıgen olduğu ve yapının duvarına bağlı oldukları belirtilmektedir ${ }^{69}$ Son cemaat mahallinden girilen minarelerden yivli gövdeli olan ve belgede kule şeklinde tarif edileni câmiin kuzeydoğu köşesinde (Fotoğraf:16), onaltıgen olarak belirtileni ise kuzeybatı köşesindedir. ${ }^{70}$ (Fotoğraf:17)

Belgede "Ve 'imâret öñunde bir 'âlî şadırvan olmışdur ki, ḥavẓınuñ

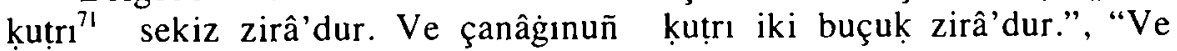
mut'ime-hâne önünde bir şadırvan olmışdur, țalebe ta'âmdan çıkınca șu içüp elin yûmak içün." şeklinde geçen bilgilerden külliyenin avlusunda iki şadırvanın bulunduğu anlaşılmaktadır. ${ }^{72} \mathrm{Bu}$ şadırvanlardan imâretin

${ }^{6}$ Ters "T" tipi, zâviyeli ya da tabhaneli olarak anılan bu tür yapılardan, gerck kitâbelerinde, gerek devirlerinin kaynaklanında ve gerekse kısmen adlarında "imaret" adını muhafaza eden yapılara şunlar ömek gösterilmektedir:Hüdâvendigâr (Bursa), Orhan Gazi (Bursa), Nilüfer Hatun (İznik), Yıldırım I.Bayazıd (Edirnc), I. Bayazıd (Balıkesir), Şahabeddin Paşa (Filibe), Yakup Çclebi (Kütahya), Karacabey (Ankara), Gedik Ahmet Paşa (Afyon), İshak Paşa (Selânik), Gülbahar Hatun (Trabzon) İmâretleri (Bkz. Eyice, a.g.m., s.23)

${ }^{67}$ Bkz. Aslanapa, a.g.e., s. 25-27, 91-93; E. Hakkı Ayverdi, Osmanl Mimârîsinde Fâtih Devri, 855-886 (1451-1481), III, İstanbul 1973, s.1-16, Istanbul Mi'mârî Çă̆ının Menşe'i Osmanlı Mimârísinin Ilk Devri, 630-805 (1230-1402), İstanbul 1966, s.419-440.

${ }^{68}$ Şânizdeh: Farsça sözlükte şânzdeh şeklinde geçen bu kelime onaltı anlamına gelmektedir (Kanar, a.g.e., s.710).

${ }^{69}$ Bu tür câmilerdcki minareler hakkında bkz. Ali Osman Uysal. "Zaviyeli Camilerde Minare Problemi", Türk Etnografya Dergisi, Sayı: XX, Ankara 1997, s.47-63.

${ }^{70}$ Minareler hakkında geniş bilgi için bkz. Yüksel, a.g.e., s.21

${ }^{71}$ Kutrı: Çapı.

${ }^{72} \mathrm{Bu}$ şadırvanlar dışında külliyede, 1812 'de Ayşe Hâtun'un yaptırdığı küçük bir şadırvan, 1820 'de Teberdârân-1 Hassadan Kâtip-zâde Esseyyid Elhac Osman Ağa'nın câmiin batısında yaptırdığı kar sebili, 1840 'da Kapancı-zâde Elhac Hüseyin Zeki Efendi'nin muvakkithâne önünde inşâ ettirdiği ufak bir şadırvan ve 1911'de Mchmed Hamdi Efendi’nin Mekteb-i İbtidâî'nin batısındaki duvarın önünde yaptırdığı şadırvan 
önündeki ve büyük bir ihtimalle câmiin kuzeyindeki bugünküi şadırvanın ${ }^{73}$ yerinde bulunan ve "âlı̂" (büyük) olarak nitelendirilen şadırvanın havuzunun çapı sekiz zira' yaklaşık $6.064 \mathrm{~m}$., ortasındaki çanağın çapının ise iki buçuk zira' yaklaş̧ı $1.995 \mathrm{~m}$. olduğu belirtilirken, mutimehânenin önünde bulunduğu zikredilen ve bugün mevcut olmayan diğer şadırvanın, yemekten çıkan talebelerin ellerini yıkamaları ve su içmeleri için yapıldığından başka, ölçüleri ve diğer özellikleri hakkında herhangi bir bilgi verilmemektedir. ${ }^{74}$ (Fotoğraf: 18)

Belgede "büyük şadırvanuñ ayaġına dört hüucre ḩalâ yapılmışdur her birinde bir lüle șu akar, țạâret içün." şeklinde verilen bilgilerden câmiin kuzeyindeki şadırvandan kullanılan suyun aktığı dört bölmeli bir helânın bulunduğu anlaşılmaktadır. Suyun akış yönü ve Gabriel'in vaziyet plânından bu helânın avlunun kuzeydoğusunda olduğu anlaşılmaktadır. ${ }^{75}$

\section{Medrese}

Câmiin batısında yer alan ve onunla birlikte 1486 yılında, güneydeki dershanenin iki tarafına üç kol biçiminde dizilen on sekiz odalı olarak inşa edilen (Şekil:3), külliyenin diğer yapılarıyla birlikte 1591 ve 1668-1669 depremlerinde büyük zarar gördügüü bilinen ${ }^{76} 1939$ ve 1943 depreminde ise önemli bir bölümü yıkıldıktan sonra 1952-1971 yılları arasında Vakıflar Genel Müdürlüğü tarafından tamir ettirilen ve günümüzde kütüphane olarak kullanılan medrese" ile ilgili belgede şu bilgiler verilmektedir: "Ve medreseñün ders-hânesinüñ tûlı ve arẓı on dörder zirâ'dur. Ve kaddi yigirmi bir zirâ'dur. Ve on yedi hüucre ve bir mu'îd ${ }^{78}$ șuffesi olmışdur ki, țulları ve arẓları bişer zirâ'dur. Ve ḥucurâtuñ revîşi on altı yîk-pâre țâş direkdür. Ve

bulunmaktaydı(bkz.Abdi-zâde Hüseyin Hüsameddin, a.g.e., s.106-107; Yüksel, a.g.e., s. 23). Ancak bu şadırvanların hiçbirisi günümüze ulaşmamıştır.

${ }^{73}$ Son devirlerde yenilenen ve çevresi $15.30 \mathrm{~m}$. olan bugünkü şadırvanın havuz kısmı mermerden yuvarlaktır ve ortasında büyük bir çanak vardır. On iki ahşap direğc binen geniş saçaklı örtüsü, Selçuklu kümbetlerine benzer sivri külahlı olup içeriden kubbelidir (bkz. Yükscl, a.g.e.. s.26). Şadırvandaki bugün kaybolmak üzcre olan süslemelerin yaklaşık 1970’li yıllarda Mehmed Emin Kutsal tarafından onarıldığı belirtilerek. Merzifon'daki Kara Mustafa Paşa Câmii şadırvanının 1875 tarihli süslemclerini yapan Zileli Emin adlı ressam ile bağlantısı hakkında ise farklı görüşler ileri sürülmektedir (bkz. Günsel Renda, "II. Bâyezid Külliyesinde Muvakkithâne", I.Ü. Ed. Fak. Sanat Tarihi Yıllı̆̆ı. IV.. 1974-1975, s.190; Rüçhan Arık. Bathlılaşma Dönemi Anadolu Tasvir Sunatı, Ankara 1988, s.53, 68-80).

${ }^{74}$ Şadırvanlar hakkında geniş bilgi için bkz. Yılmaz Önge, Türk Mimarisinde Selçuklu ve Osmanlı Dönemlerinde Su Yaptlart, Ankara 1997, s.80-94.

${ }^{75}$ Bkz. Gabriel, a.g.e., fig. 22.

${ }^{76}$ Bkz. Hüscyin Hüsameddin. a.g.e., s.105-106.

n Medrese hakkında geniş bilgi için bkz. Yekta Demiralp, Erken Dönem Osmanlı Medreseleri(1300-1500), Ankara 1999, s.141-145 resim:105-111; Yüksel.a.g.e., s.26-28

${ }^{78}$ Muid: Medresclerde müzakerecilik yapanlar ile müderris yardımcılığında bulunanlar hakkında kullanılan bir kavram olup, sahn medresclerinde hücre sahibi olanlar ve liyakatli bulunanlar da bu ismi alırlardı (Pakalın, a.g.e., s.573). 
üzerlerinde tolos ${ }^{79}$ yapılmışdur. Ve ḥucurâtuñ öñleri seküler bağlanmışdur. Ve ortasında bir şadırvan olmışdur. Ve üç hüucre ḩalâ ve bir țahâret-hâne ki, içinde bir lüle su aḳar. Cümle hụcurât ve ders-hâne yigirmi kubbedür."

Buna göre medresenin, $14 \times 14$ zira'(yaklaşık $10.612 \times 10.612 \mathrm{~m}$.) ebatlarında bir derhanesi, on altı sütunun taşıdığı tonoz örtülü revaklarla çevrili ve önlerinde sekiler olan, $5 \times 5$ zira' (yaklaşık $3.790 \times 3.790 \mathrm{~m}$.) ölçülerinde on yedi odası, aynı ebatlarda bir muîd sofası, içinde bir lüle su akan bir tahârethânesi ve üç bölmeli helâsı ile avlu ortasında, havuzu bugün de mevcut olan bir şadırvanının bulunduğu anlaşılmaktadır.

Medresenin ayn zamanda mescidi olan dershanesinin bugünkü $7.90 \times 7.83 \mathrm{~m}$. ölçüleri ile belgede verilen ölçüleri arasında büyük bir fark varken, odaların belirtilen ölçüleri bugünkü ölçülere oldukça yakındır ${ }^{80}$ Belgede belirtildiği gibi medresede irili ufaklı yirmi kubbe vardır. "Mu'id suffesi”yle medresenin neresinin kasdedildiği açık bir şekilde anlaşılmamaktadır. Ancak, burasının büyük bir ihtimalle dershanenin kuzeyindeki kubbeyle örtülü bölümün olduğunu tahmin ediyoruz. Çünkü, belgede câmiin anlatıldığı kısımda "suffe" kavramıla belirtilmek istenilen şeyler ve dershanenin önündeki mekânın medresenin odaları gibi kubbeyle örtülerek vurgulanması bu görüşümüzü destekler mahiyettedir.

Medrese revakının on altı yekpâre taş direkli (sütunlu) olduğu belirtildiği hâlde günümüzde bunların sayısı on dörttür. Her iki kanatta da revakların en kuzey uçlarındaki kemerler bugün duvara binmektedir. Medreseyi anlatan kişinin bir sayım hatası yapmadığı kabul edilirse, medrese revaklarının en kuzeydeki kemerlerin eskiden gömme sütunlara bindiği, ancak bu sütunların, 1591, 1668-1669 veya 1939 depreminden sonra medresede yapilan tamirlerin birinde, ya kaldırıldığ ya da medresenin bu cephesinde bazı değişikliklere gidilmiş olabileceği sonucuna ulaşılmaktadır. Zaten avlu ihata duvarı ile revakların kuzey taraflarını kapatan duvarlar arasında bitişme çizgilerinin olması ve her iki duvardaki derz sıralarının birbirini izlememesi, avluyu kapatan kuzeydeki duvarın medresenin orijinal yapısında olmadığını açıkça göstermektedir. ${ }^{81} \mathrm{~A}$. Gabriel'in son tamirden önce çizdiği vaziyet planında ve restitüsyon çiziminde bu duvarın gösterilmemesine dayanılarak burasının son onarımda yapıldı $\breve{g}$ ileri sürülmektedir. ${ }^{82}$

Belgede "Ve üç hüucre halâ ve bir țahâret-ḩâne ki, içinde bir lüle su aḳar." şeklinde verilen bilgiyi medresenin, içinde bir lüle su bulunan, bir odasının helâ ve tahârethâne (banyo) olarak kullanılḍ̛̆ını ve helânın üç bölmeli olduğu şeklinde anlamak gerekir. Çünkü, medresenin on sekiz odası olduğu halde, on yedi hücresi bulunduğu belirtilerek, helâ ve banyo olarak kullanılan mekân medresenin hücresi kabul edilmemiştir. Helâ ve banyoya

\footnotetext{
${ }^{79}$ Tolos: Tonoz.

Bkz. Yükscl, a.g.e., s.26-28.

${ }^{81}$ Bkz. Demiralp, a.g.e., s.142, resim: 108.

${ }^{82}$ Bkz. Demiralp, a.g.e., s.142-143; Gabriel, a.g.e., fig. 21, 22.
} 
tahsis edilen odanın, hangi oda olduğu açıkça belirtilmemektedir. Ancak, büyük bir ihtimalle bu oda, medresenin kuzey batı ucunda yer alan ve bugün de hâlâ aynı amaçlarla kullanılan oda olabilir. Bu hücrenin kuzey duvarının revak duvarına göre daha ince yapılıp odanın diğerlerinden daha büyük olmasının sağlanması ve diğger hiçbir odada revaka açılan pencere olmadığı hâlde bu odada açılarak ${ }^{83}$, odanın içinin daha fazla hava almasının temin edilmesi, eskiden beri burasının helâ ve banyo olarak kullanıldığının delilleri sayılabilir.

\section{İmâret}

Câmiin doğusunda yer alan imâret "L" biçimindedir. Revaka açılan dört kapıdan beş ayrı bölüme geçilmektedir. Belgede bu yapı imâret kavramıyla değil de, mut'imehâne, matbah, kiler, fırın ve ahır gibi fonksiyonları açıkça belirtilen ayrı ayrı yapılar olarak anlatılmaktadır. (Şekil:4) Ayrıca, "Ve mut'ime-ḩânenüñ ve maţbahuñ ve kilaruñ ve furunuñ ve ahuruñ önlerinde on bir yîk-pâre țaş direk ve on iki kubbe revîş olmışdur." şeklinde geçen ifadeyle bu yapıların önünde on bir taş sütunlu ve on iki kubbeyle örtülü bir revakın bulunduğu belirtilmektedir. Revak bugün de on bir sütunludur. On iki değil de on kubbeyle örtülüdür. Ayrıca, ahır olarak belirtilen yapının batısındaki revakın kuzey ucundaki geniş kemerli bölüm aynalı tonozla kapatılmıştır. Belgede verilen kubbe sayısının bugünküyle tutmamasının sebebi, muhtemelen yapılan tamirlerde burada yapılan değişiklikler ve kubbe sayısının bir fazla gösterilmesidir. Çünkü yapı 1939 ve 1943 yıllarındaki depremlerde büyük hasar görmüş ve 1952-1971 yılları arasında büyük onarım geçirmiştir. (Fotoğraf: 19, 20) Belgede, imâret (câmi) ve medresenin tamamen kurşunlandığ 1 yani câmi ve medresenin örtülerinin üstten kurşunla kaplandığı hâlde, kurşun örtünün pahalı olduğundan mut'imehâne, matbah, kiler, fırın, ahır ve aşağıda değineceğimiz muallimhânenin kurşunlanmadığı belirtilmektedir.

Şimdi bugün imaret olarak bilinen ve beş ayrı bölümden oluşan bu yapının kısımlarını belgede belirtildiği sırasına göre ayrı ayrı inceleyelim:

1-Mut'imehâne: Yemekhâne anlamında belgede bu iki isimle anılan yapının, $14 \times 14$ zira' yaklaşık $10.612 \times 10.612 \mathrm{~m}$. ebatlarında olduğu ve şadırvanlar bölümünde değindiğimiz gibi yemekten çıkınca öğrencilerin ellerini yıkamaları için önünde bir şadırvanın bulunduğu belirtilmektedir. Kuzeydeki revaktan basık kemerli bir kapıyla girilen yemekhane, belgede verilen ölçüler gibi kare şekilli olmayıp, yaklaşık 10x9 m. ebatlarında kuzeygüney istikâmetine doğru uzanan ve ortasında kare bir ayak bulunan, tonoz örtülü dikdörtgen plânlıdır. ${ }^{84}$ Güney ve batı duvarındakiler altlı üstlü olmak üzere toplam dokuz pencereden ışık alan yemekhane, doğusundaki mutfağa bir servis penceresiyle bağlanmışır.

\footnotetext{
${ }^{83}$ Bkz. Demiralp, a.g.e., s. 144, şckil: 66

${ }^{8}$ Bkz.Yüksel, a.g.e. s.30, şckil: 13.
} 
2-Matbah: Belgede matbahla ilgili şu bilgiler verilmektedir: "Ve mațbahuñ tûlı on sekiz zirâ'dur (yaklaşık $13.644 \mathrm{~m}$.). Ve arẓı on dört zirâ'dur (yaklaşık $10.612 \mathrm{~m}$.). Ve ortasında iki direk vâki' olmışdur. Direklerüñ bir țarafında üç kubbe olmuşdur. Ocak içün depeleri açuḳdur. Ammâ direcükler üzerine kubbecükler olmuşdur. Ve bir țarafına ol üç kubbe uzunu tolos olmışdur. Ve iki daḩi müsâfir ocakları olmışdur. Ve her bir kazgâna başka bir lüle șu aḳar." l. Aydın Yüksel'in buradaki iki ocağa dayanarak "pişirme yeri" olarak tarif ettiği ${ }^{85}$, sözlüklerde ise "mutfak, yemek pişirilen yer" anlamına gelen "matbah" ${ }^{86}$, bugünkü gibi ortadaki iki ayağın güney tarafının, tepeleri açık yani aydınlık fenerli üç kubbeyle, kuzey tarafının ise tonozla örtülü olduğu ve her birine ayrı birer lüle su akan iki ocağın bulunduğu anlaşılmaktadır. Bugün $10.87 \times 17.25 \mathrm{~m}$. ölçülerindeki mutfak, güneye açılan üç mazgal pencere ve revaka açılan diğer iki pencereyle aydınlanmaktadır. Yukarıda geçen "Ammâ direcükler üzerine kubbecükler olmuşdur." ifadesiyle muhtemelen, her iki ayağın üzerinde bugün de mevcut olan delik pencereler kasdedilmektedir. ${ }^{87}$ (Fotoğraf:21, 22)

3-Kilar: Belgede kilar "Ve kilaruñ (yaklaşık 12.128x12.128 m.). Ve içinde bir anbar olmışdur, biş gözlü, ikisi birinc içün ve üç gözi gayri havâyic içün" şeklinde tarif edilmektedir. Buna göre kiler, kare plânlıdır ve içinde beş dolap nişi vardır. Bu nişlerden, ikisinin pirinç koymak diğer üçünün ise başka ihtiyaçlar amacıyla kullanıldığı belirtilmektedir. Abdi-zâde Hüseyin Hüsameddin'in de "kiler" ve "aynî öşür anbarı" olarak nitelendirdiği bu oda ${ }^{89}$ bugün $8.85 \times 10.22 \mathrm{~m}$. ebatlarında dikdörtgen şekilli olup, duvarlarında da altlı üstlü toplam otuzdört tane dolap nişi vardır. Basık çapraz bir tonozla örtülüdür. Doğu ve güney duvarında ikişer olmak üzere dört mazgal pencereden 1 şık almaktadır. ${ }^{90}$

4-Fırın: Belgede fırınla ilgili şu bilgiler verilmektedir: "Ve furunuñ ț̂̂lı on altı zirâ'(yaklaşık $12.128 \mathrm{~m}$.) ve arz̧ı on dört zirâ'(yaklaşık $10.612 \mathrm{~m}$.) dur. Ve içinde bir anbar olmışdur iki gözlü. Ve ocağı içinde bir lüle konmışdur kazg̣ânına su aḳar." Fırın olarak belirtilen mekân kilerin kuzeyindeki bölüm olup $11.15 \times 9.00 \mathrm{~m}$. ebatlarındadır. İki gözlü anbar şeklinde tarif edilen fakat hangi duvarda bulunduğu belirtilmeyen dolap nişi ise bugün mevcut değildir. Günümüze ulaşmış olan ocak, batı duvarından revaka açılan pencere ile kapı arasındadır. Ortadan bir kemerle ikiye ayrılmış olan fırının güneyi yarım çapraz tonozla kuzeyi ise beşik tonozla örtülüdür.

\footnotetext{
${ }^{85}$ Bk7.Yükscl, a.g.e., s.30.

${ }^{\$ 3}$ Bkz. Şemseddin Sami, a.g.e., s. 1362

${ }^{k 7}$ Bkz. Yükscl, a.g.e., s.30.

${ }^{83}$ Günümüzde kiler olarak telaffuz edilen kilar, yiyecek ve içecck mađdelerinin tükctilinceye kadar saklanıp muhafaza cdildikleri odadır. Osmanlılar döneminde sarayın yiyecek ve içeceklerinin korunduğu mekîna "Kilâr-1 Amire" denirdi (Bkz. Pakalın, a.g.e., C.II, s.281).

*) Abdi-zâde Hüseyin Hüsameddin, a.g.e., s.103.

${ }^{\text {() }}$ Geniş bilgi için bkz.. Yüksel, a.g.e., s.30, şekil: 12.
} 
Bu örtüsü sistemi ve belgede belirtilen dolap nişinin kapatılmasından değişikliğe uğrayarak günümüze ulaşan fırın bölümü doğu duvarındaki iki mazgal ve batı duvarındaki dikdörtgen şekilli bir pencereden 1 şık almaktadır. ${ }^{91}$ Abdi-zâde Hüseyin Hüsameddin'in verdiği bilgilerden, belgede fırın olarak anlatılan bu bölüm ile aşağıda izah edeceğimiz ahır kısmının, 19. yüzyılın sonları ile 20. yüzyılın başlarında, tabhâne yani misafirhane ve askerî silah deposu olarak kullanıldı $\breve{g}_{1}$ anlaşılmaktadır. ${ }^{42}$

5-Ahır: Belgede ahırın sadece $24 \times 16$ zira'(18.192x12.128 m.) lık ebatları verilmiş ve kapısı önünde misafirlerin atlarına su vermek için bir çeşmenin bulunduğu ve aynı zamanda bu çeşmenin suyunun mahalleye kâfi geldiği belirtilmiştir. Ahırın bugünkü ölçüleri $16.50 \times 11: 30 \mathrm{~m}$. olup bahsedilen çeşmeden de günümüze hiçbir şey kalmamıştır. İ. Aydın Yüksel'in, hacmin genişliğinden hareketle burasının ahır olabileceği fikrini $i^{93}$ böylece belge teyit etmektedir. İki yuvarlak kemer destekli beşik tonozla örtülü olan ahıra kuzey ve kuzeybatıdaki iki kapıdan girilmektedir. Kuzeydeki kapı bir atın rahatlıkla girebileceği yükseklik ve genişliğe sahip olduğu hâlde, revaka açılan diğer kapı ancak insanların girip çıkabileceği ebatlardadır. 1939 yılındaki depremde üst örtüsü ve revakı tamamen çökmüştür. Muhtemelen 1940'lı yıllarda, çöken bu revakın yerine helâlar yapılmıştır. 1952-1971 yılları arasındaki onarımlarda bu helâlar kaldırılarak bugünkü revak yapılmıştır. Ahır doğu ve batı duvarlarındaki üçer mazgal pencereden ışık almaktadır.(Fotoğraf:23, 24, 25, 26)

\section{Muallimhanenin Tabhanesi}

Muallimhane hakkında bilgi verilmeyen belgede, muallimhanenin tabhanesinin $10 \times 10$ zira'(yaklaşık $7.580 \times 7.580 \mathrm{~m}$.) ölçülerinde olduğu ve $10 \times 8$ zira'(yaklaşık $7.580 \times 6.064 \mathrm{~m}$.)ebatlarında bir dış sofasının bulunduğu belirtilmektedir. Belgedeki bilgilerden avlunun neresinde olduğu anlaşılmayan bu yapı, şayet 19. yüzyılın sonlarına ulaşabilmişse, Abdi-zâde Hüseyin Hüsameddin "ahırın önünde batıya nazır ve hattatlara mahsus bir Dâru't-ta'lîm (Islâh-1 Medâris Komisyonu Odası)" şeklinde yerini ve fonksiyonunu ifade ettiği yapı olabilir. ${ }^{94} \mathrm{~A}$. Gabriel de vaziyet plânında burayı, imareti oluşturan bölümlerle beraber taralı ve batıya doğru hafif taşkın olarak göstermektedir. ${ }^{95}$

\section{Matbahın Arkasındaki İki Ev ve İki Anbar}

Belgede bu iki ev ve anbar hakkında şu bilgiler verilmektedir: "Ve mațbah ardında bir ev yapılmışdur, odun ḳomaḳ içün dört biñ yük miḳdar

\footnotetext{
${ }^{91}$ Bkz. Yükscl, a.g.e., s.30.

${ }^{92}$ Abdi-zâde Hüscyin Hüsameddin, a.g.e., s.XIX-XX. 103.

${ }^{93}$ Yüksel, a.g.e., s.30.

*4 Abdi-zâde Hüseyin Hüsameddin, a.g.e., s.103

"s Bkz. Gabriel, a.g.e.. s.40. fig. 21.
} 
odun alur. Ve bir ev dahi yapılmışdur meremmet ${ }^{96}$ esbâbın ḳomaḳ içün. Ve bir anbar yapılmışdur arpa ḳomak içün üç yüz müd arpa alur. Ve bir anbar dahi yapılmışdur. Gendümmâ ${ }^{17}$ içün, yüz elli müd buğday alur." Bu bilgilere göre, evlerden birinin odun koymak diğerinin meremmetçilerin kullanmaları amacıyla, anbarların ise buğday ve arpa depolamak için yapıldığ anlaşılmaktadır. Odun konulan evin dört bin yük odunu, buğday anbarının yüz elli müd buğdayı ve arpa anbarının ise üç yüz müd arpayı aldığı belirtilmektedir. Bu ev ve anbarların hiçbirisi günümüze ulaşmamıştır.

\section{Külliyenin Avlusu}

Belgede külliyenin avlusu ile ilgili şu bilgiler verilmektedir: "Ve ḥavlî dîvârınuñ devri kim yapılmışdur, bin ikiyüz zirâ'dur. Ve ırmak kenarında olan dîvârın üzerine yonma țaş döşenmişdür adam oturmak içün. Ve 'imâret önünde olan havalînuñ dört kâpusı vardur, ikisi ırmak țarafına ve biri şehirden yaña ve biri Gök Medrese'den yañadur. Ve bir kâpu dahi mațbah ardında olmışdur arpa ve buğday țaşımmak içün ve gayri esbâb dahi olduğunca ol kâpudan işler. Ve medresenüñ ve 'imâretüñ ve mațbahuñ öñî ve ardı beraberdür. Şöyle ki, ip dutulsa bir barmak ziyâde yâ eksük olmamışdur. Ve 'imâret önünde bir kapudan bir kapuya vârınca yonma țaşla ḳaldırım olmışdur, dört zirâ' eni üç yüz elli zirâ' tûlıdur. Ve dergâh öñünde her direk mukâbelesinde birer servi ag̉acı dikilmişdür. Ve şadırvanuñ dört țarafına dört servi dikilmişdür. Ve tesbîh ağaçları dikilmişdür. Ve ırmaḳ kenarına ḳavak ağaçları dikilmişdür, gölgesi ol taş döşenmiş dıvar üstüne düşer. Ve ḳıble țarafında olan bagçeye yüz otuz aşulama dikilmişdür. Ve medrese ile 'imâret arası dizme olmışdur. Ve 'imâret ile mațbah arası dizme olmışdur. Ve mațbah ile anbarlar öñi dizme olmışdur. Ve ahur ḳapusundan halâya varınca dizme olmışdur. Havlî içine at girmesün içün gâyetde mażbût ve mahfûżdur."

Görüldüğü gibi câmiden sonra en fazla bilgi avlu hakkında verilmektedir. Buna göre avluya ırmak tarafından iki, Gök Medrese tarafından (batıdan) bir, şehir tarafından (doğudan) bir ve matbah ardında bir olmak üzere toplam beş kapının açıldığı belirtilmektedir. Bu kapılardan bugün câmiin güney tarafındaki hâriç, diğer dört kapı nisbeten özgün biçimlerini korumaktadır. Bu kapılar dışında avlu duvarları, avlu içerisindeki yapıları birbirine bağlayan kaldırımlar, helâya ve şadırvanlara giden yollar, avluya dikilen selvi, kavak ve tesbih ağaçları ile yapılar arasında kalan boşluklara sıra sıra dikilen diğer ağaçlarla ilgili verilen bu bilgiler, dönemin

\footnotetext{
* Meremmet Arapça'da onarım, ıslah ve tamir anlamlarına gelmekte olup Osmanlılar döneminde bu faaliyetleri yürüten kişilere meremmâtî veya merenımetçi deniliyordu (Bkz. Pakalın, a.g.e., C. 2. s.481: Yusuf Küçükdağ. Karapınar Sulıan Selim Külliyesi, Konya 1997, s.134; Abdulkadir Dündar, "Osmanlı Mimarîsinde Vakıf Mimarları", Prof. Dr. Haläk Karamă̆aralı Armağanı, Ankara 2002, s.113-114).

${ }^{17}$ Gendüm: Buğgay, hınta (Bk7. Şemseddin Sâmi,a.g.e.. s.1185).
} 
avlu anlayışı ve düzenlemesine açıklık getirmesi bakımından oldukça önemlidir.

\section{Sonuç}

Dört taraftan ihâta duvarlarıyla çevrili büyük bir avlu içerisinde yer alan ve inşası 1486 yılında tamamlanan Amasya II. Bayezid Külliyesi, yapılarının doğu-batı ekseninde düzenli yerleşimi ve dağılımı ile döneminin önemli külliyeleri arasında yer almaktadır. Külliyenin ana yapısı, belgede çoğunlukla imaret terimiyle ifade edilen câmidir. Arka arkaya iki büyük kubbeyle örtülü olan câmiin arka kubbenin yan kanatlarında ikişer olmak üzere, belgede belirtildiği gibi toplam dört tabhane ve bu tabhanelerin ortalarında ise yine belgenin söylemiyle birer suffe vardır. Belgede yan kanatlarla ilgili olarak açıkça mekân tanımlaması yapılması, ister istemez akıllara, bu tabhanelerin mihrap önü ile orta mckâna nasıl bağlı oldukları ve ortalarındaki suffelerle ilişkilerinin ne şekilde olduğuyla ilgili soruları getirmektedir.

Amasya'nın deprem kuşağında yer alması bu külliyeyi oluşturan yapıların özgün biçimleriyle günümüze ulaşamamasında büyük rol oynamıştır. Özellikle 1939 ve 1943 yıllarındaki depremler yapılara çok büyük hasar vermiştir. Bunun neticesi olarak külliyede 1952-1971 yılları arasında Vakıflar Genel Müdürlüğü'nce gerçekleştirilen onarımlarda, belgede câmiin kubbelerinde, duvarlarında ve son cemaat yerinde bulunduğu belirtilen kalem işleri süslemeler ilc yazılar tamamen ortadan kaldırılarak sadece kubbelere, eteklerine ve geçiş unsurlarına yeni süslemeler yapılmıştır.

Belgede ağırlıklı olarak câmi hakkında bilgi verilmiştir. Dolayısıyla imaret kavramıyla ifade edilen câmiin iki büyük kubbesi, mihrabı, minberi, dört tabhanesi, iki suffesi, üç girişi, pencereleri, içten içe ölçüleri, iki minaresi, son cemaat yeri, taçkapısı ve süslemeleri özet bir şekilde anlatılmıştır. Belgede verilen bu bilgiler, câmiin özgün biçimi ve süslemelerini büyük bir oranda ortaya koyarak, bugünkü durumunun sağlıklı bir şekilde değerlendirilmesine önemli katkılar sağlamaktadır.

Belgede medreseyle ilgili olarak çok az bilgi verilmektedir. Ancak verilen bu bilgiler, medresedeki oda sayısının on yedi olarak belirtilip helâ ve taharethane olarak kullanılan hücrenin bu sayıya dâhil edilmemesi; muid suffesinden bahsedilmesi ayrıca hücre önlerindeki revakın on altı sütunlu olduğunun vurgulanması; bu medresede hangi odanın helâ-taharethane olarak kullanıldığına, muid suffesinin medresede neresi olduğuna, revakın özgün biçimine ve dolayısıyla da avluyu kapatan kuzey duvarının durumuna büyük açıklık getirmektedir.

Belgenin Osmanlı sanat ve mimarisi bakımından yukarıda belirttiklerimizin dişında diğer önemli bir yanı, Amasya II. Bayezid İmareti hakkında verdiği bilgilerdir. Belgede bu yapı imaret terimiyle anılmayıp, mut'imehane, matbah, kilar, fırın ve ahırdan oluşan beş fonksiyonlu bir bina olarak anlatılmıştır. Böylece bir imaretteki bölümlerin vazifeleri ve hangi 
amaçlara yönelik kullanıldıkları döneminin orijinal bir belgesiyle açıklığa kavuşmaktadır. Ayrıca, özgün biçimini büyük bir oranda kaybederek günümüze ulaşan Amasya II. Bayezid imaretinin orijinal şekli de bu belgedeki bilgilerle vuzuha kavuşmaktadır.

Belgede ayrıca, dış suffesi olan muallimhane tabhanesinden, matbahın arkasındaki iki ev ve iki anbardan ve büyük şadırvanın ayağına yapılmış olan dört hücreli helâ hakkında bilgi verilmektedir ki, bu yapıların hiçbirisi de günümüze ulaşmamıştır. Dolayısıyla bugün mevcut olmayan bu yapılar, mut'imehane önündeki şadırvan ve tabhanelerin suffeler ve iç mekânlarla bağlantılarının, belgede verilen bilgiler ışığında yapılacak sondaj ve ufak çaptaki kazılarla ortaya çıkarılabilineceğini düşünmekteyiz.

Belgede su tesisi olarak üç şadırvan ve bir çeşmeden bahsedilmektedir. Şadırvanlardan birisi, yuvarlak havuzu ve fıskiyesi bugün de mevcut olan, medresenin avlusundaki, diğeri mut'imehane önünde olduğu belirtilen ve günümüze ulaşamayan şadırvan, bir diğeri ise "âlî" yani büyük olarak nitelendirilen ve câmiin kuzeyindeki, muhtemelen su teknesi ve ortasındaki çanağı orijinal olan ancak örtüsü belirtildiği gibi 19. yüzyılın ikinci yarısına ait olan bugünkü şadırvan, çeşme ise ahırın önünde olduğu zikredilen ancak günümüze ulaşamayan çeşmedir.

Amasya II. Bayezid Külliyesi'nin ihata duvarlarıyla çevrili avlu içerisinde yer alan yapılar ve avlu düzenlemesi tamamlandıktan sonra yazıldığı anlaşılan bu belge, külliyeyi oluşturan bugün mevcut olan veya olmayan yapılar, avlunun duvarları, bu avluya açılan kapılar ve avlunun düzeni hakkında verdiği bilgiler bakımından önemli olduğu kadar; yapılar anlatılırken kullanılan, imaret, kubbe koltukları, şemse, vezirî cam pencere, mukatta' kapu, düvâzde çenber-girih, demir muhaccerli suffe, sâde kilvekârî, dehi-girih, revişi imaret, müdevver direk, dergah kubbesi, kemer pervâzı, şeşi-girih, yeşim taş, nîm çarşıları, müselles rûmi yaprak, kened, kilvedâr, kızıl taş kahmak, büyük âvize, küçük âvize, tabhâne, medrese dershanesi, mu'id suffesi, hucurâtın revişi, yîk-pâre taş direk, tolos, âli şadırvan, hücre, halâ, taharethane, mut'imehane, matbah, kilar, fırın, ahır, anbar, taşra suffe, meremmet, anbar ve yonma taş gibi metin içerisinde yeri geldikçe açıkladığımız terimler bakımından da büyük bir önemi haizdir.

\section{Belgenin Transkripsiyonu}

Bu tafsîl Amasiyye'de olan 'imâretüñ ve medresenüuñ binâların beyân ider ki zikr olınur: Câmi` iki âlî kubbedür. Ve ol iki kubbenüñ ortasında bir kemer var, kâlıñı üç zirâ'dur, içinde cift asılmışdur. Ve öñ kubbenüñ koltukları mukarnașdur, naḳs olmışdur. Ve gerideki kubbenüñ ḳoltukları sâdedür, birer şemse yazılmışdur. Ve öñ kubbenüñ ortasında bir büyük şemse olmışdur, şemsenün orutası müșennâ hatțıle "İnne evvele beytin vựı' 'a.." âyeti yazılmışdur. Ve pervâzı naķş olmışdur. Ve gerideki kubbenüñ daḩi ortasında bir şemse var. Ortası naḳş ve pervâzı müșennâ ḩațțle "İnnemıâ ya'muru mesâcida'llâhi..." âyeti yazılmışdur. Ve öñ kubbenüñ aşag̉a 
dîvârlarında dört şemse yazılmışdur. Ve gerideki kubbe dîvârlarında iki 'âlî şemse yazılmışdur. Ve kemerlere țaş mevc țarh olmışdur. Ve yigirmi bir muḳațta' ve $e^{98}$ vezin̂ câm pencereler olmışdur. Ve on pencere dahi muḳața' kâpûlu olmışdur. Ve iki kâpû dahi șuffelere açılur. İç yüzlerine mukatța' kâpûlar așılmışdur. Ve țaş yüzlerine demürden düvâzde çenber-girih kâpûlar işlenmişdür, açılur, yapılur. Ve câmi'üñ büyük kâpûsınuñ iç yüzinde üzerinde demür muhaccerlü bir șuffe olmışdur. Ve câmi' içinüñ tụ̂lı kırk iki zirâ'dur. Ve arẓı yigirmi bir zirâ'dur. Ve kaddi otuz üç zirâ'dur. Ve ak mermerden miḷrâb işlenmişdür, muḳarnaşdur. Ve minber işlenmişdür, ak mermerden sâde kilvekârî. Ve ḳâpûsî dahi aḳ mermerdendür. Dehi-girih kazılmışdur, açılur, yapıllur. Ve yüz elli üç zencîr aṣılmışdur. Kânâdîl içün her kubbede üçer dâyire olmışdur.

Ve revişi 'imâret ki, țûlı elli zirâ'dur. Ve arẓı dokuz zirâ'dur. Ve altı mermer müdevver direk olmışdur. Ve başları muḳarnaṣdur. Ve dergâh kubbesi penc kubbe muḳarnaş işlenmişdür. Ve kubbe-i mezkûrenüñ kemerleri ciftlüdür. Ve dergâh kemerlerinüñ pervâzları şeşi-girih işlenüp yeşim țaş geçmişdür. Ve nîm çârşûları müselles rûmî yaprak resm olup kened olmışdur. Ve naḳş dâyiresine kilvedâr ḳızıl taş kaḥmışdur ${ }^{99}$. Ve naķ̧̣ üzerinde bir kitâbe olmışdur. Bir minâreden bir minâreye varınca "Innâ fetahnâ..." sûresi müsenna haț̣̂le yazılup kazılmışdur. Ve ḳafa tahta aḳ mermerden bîş-kû muḳarnaș işlenmişdür. Kâpû dergâhı ki, muḳarnaș işlenmişdür. Üç büyük âvizesi var. Ve on sekiz küçük âvizesi vardur. Ve 'imâret dîvârınuñ kalıñı üç zirâ'dur.

Ve dört tâb-ḥâne olmuşdur, dîvârlarından gayrı içlerînüñ tûlı ve arẓı sekizer zirâ'dur. Ve iki șuffe ki tâb-ḥâneler öñündedür, țulları ve arẓları tokuzar zirâ'dur. Ve iki minâre olmışdur, biri kule ve biri şânizdeh duțuğnukdur. Ve 'imâret öñünde bir 'âlî şadırvan olmışdur ki, havžnınuñ ḳuṭı sekiz zirâ'dur. Ve çanâġınuñ ${ }^{100}$ kuțịi iki buçuk zirâ'dur.

Ve medreseñün ders-hânesinüñ țûlı ve arẓı on dörder zirâ'dur. Ve ḳaddi yigirmi bir zirâ'dur. Ve on yedi hüucre ve bir mu'îd șuffesi olmışdur ki, tûlları ve arz̧ları bişer zirâ'dur. Ve hucurâtuñ revîşi on altı yîk-pâre țâş direkdür. Ve üzerlerinde tolos yapılmışdur. Ve hucurâtuñ öñleri seküler bağlanmışdur. Ve ortasında bir şadırvan olmışdur. Ve üç hüure halâ ve bir tahâret-ḩâne ki, içinde bir lüle su aḳar. Cümle hucurât ve ders-ḩâne yigirmi kubbedür.

Ve mut'ime-ḩânenüñ țûlı ve arẓı ondörder zirâ'dur. Ve mațbahuñ tûlı on sekiz zirâ'dur. Ve arẓı on dört zirâ'dur. Ve ortasında iki direk vấki' olmışdur. Direklerüñ bir țarafında üç kubbe olmuşdur. Ocak içün depeleri açụ̂dur. Ammâ direcükler üzerine kubbecükler olmuşdur. Ve bir țarafına ol

\footnotetext{
"Muhtemelen buradaki harckeli ilk "vav" harfi fazladan yazılmıştır.

") Kahmı̧̧dur kelimesinin ilk harfi "kaf" harfi olması gerekirken "kef" harfiyle yazılmıştır.

${ }^{10 x}$ Belgede "hanagınun" şcklinde geçen kelimenin ilk harfi olan "h" harfinin altına sehven nokta konulmadığını düşünerek, bu kelimeyi "çanagınun" şcklinde verdik. Ayrıca sözlüklerde "hanagınun" şeklinde bir kclimeye rastlanılmamaktadır.
} 
üç kubbe, uzunu tolos olmışdur. Ve iki dahi müsâfir ocakları olmışdur. Ve her bir ḳazgâna başka bir lüle șu aḳar. Ve kilaruñ tûlı ve arẓı on altışar zirâ'dur. Ve içinde bir anbar olmışdur, biş gözlü, ikisi birinc içün ve üç gözi gayri havâyic içün. Ve furunuñ ț̣̂lı on altı zirâ' ve arẓı on dört zirâ'dur. Ve içinde bir anbar olmışdur iki gözlü. Ve ocağı içinde bir lüle ḳonmışdur ḳazgânına șu aḳar. Ve ahurun dahi tûlı yigirmi dört zirâ'dur. Ve arẓı on altı zirâ'dur. Ve kâpûsı önünde bir çeşme olmışdur, müsâfir atın șuvarmak içün. Ve mahalleye kifâyet ider. Ve mut'ime-ḩâne öñünde bir şadırvan olmışdur, țalebe ta'âmdan çıkınca șu içüp elin yûmak içün. Ve mut'ime-ḩânenüñ ve matbahuñ ve kilaruñ ve furunuñ ve ahuruñ önlerinde on bir yîk-pâre tạ̧ direk ve on iki kubbe revîş olmışdur.

Ve mu'allim-ḩânenüñ tâb-ḩânesi tûlı ve arẓı onar zirâ'dur. Ve țaşra suffesinüñ tûlı on zira' ve arẓı sekiz zirâ'dur. Ve 'imâret ve medrese temâm ḳurşunlanmışdur. Ve bâkî mut'ime-hâne ve mațbah ve kilar ve furun ve ahurur ve mu'allim-hâne kưş̧unlanmamışdur, kurşun bahâya çıḳdugî́çun. Ve mațbah ardında bir ev yapilmışdur, odun ḳomak içün dört biñ yük miḳdar odun alur. Ve bir ev dahi yapılmışdur meremmet esbâbın ḳomak içün. Ve bir anbar yapılmışdur arpa ḳomak içün üç yüz müd arpa alur. Ve bir anbar dahi yapılmışdur. Gendümmâ içün, yüz elli müd buğday alur. Ve büyük şadırvanuñ ayağına dört hüucre halâ yapılmışdur her birinde bir lüle șu aḳar, tahâret içün. Ve 'imâret ḥavlısınuñ țûlı üç yüz elli zirâ'dur. Ve arẓı ikiyüz elli zirâ'dur. Ve iki sed dahi olmışdur ki, biri ḳıble tarafındadur, kalıñı bir buçuk zirâ'dur ve tûlı uiçyüz elli zirâ'dur. Ve bir sed dahi ırmak kenarında olmışdur, kalıñı iki zirâ' țûlı üçyüz yetmiş zirầ'dur.

Ve havlî dîvârınuñ devri kim yapılmışdur, bin ikiyüz zirâ'dur. Ve ırmaḳ kenarında olan dîvârın üzerine yonma țaş döşenmişdür adam oturmak içün. Ve 'imâret önüunde olan havlînuñ dört ḳâpusı vardur, ikisi ırmak tarafına ve biri şehirden yaña ve biri Gök Medrese'den yañadur. Ve bir ḳâpu dahi mațbah ardında olmışdur arpa ve buğday țaşınmak içün ve gayri esbâb daḩi olduğunca ol kâpudan işler. Ve medresenüñ ve 'imâretữn ve mațbahuñ öñ̂i ve ardı beraberdür. Şöyle ki, ip dutulsa bir barmak ziyâde yâ eksük olmamışdur. Ve 'imâret öñünde bir ḳapudan bir ḳapuya vârınca yonma țaşla kaldırım olmışdur, dört zirâ' eni üçyüz elli zirâ' tụ̂lıdur. Ve dergâh önüunde her direk mukâabelesinde birer servi ağacı dikilmişdür. Ve şadırvanuñ dört țarafına dört servi dikilmişdür. Ve tesbîh ağaçları dikilmişdür. Ve ırmak kenarına kavak ağaçları dikilmişdür, gölgesi ol ța̧ döşenmiş dıvar üstüne düşer. Ve ḳıble țarafında olan baģçeye yüz otuz aşulama dikilmişdür. Ve medrese ile 'imâret arası dizme olmışdur. Ve 'imâret ile mațbah arası dizme olmışdur. Ve mațbah ile anbarlar öñi dizme olmışdur. Ve ahur kapusundan halâya varınca dizme olmışdur. Havlî içine at girmesün içün gâyetde mażbût ve mahfûżdur. Temme. 


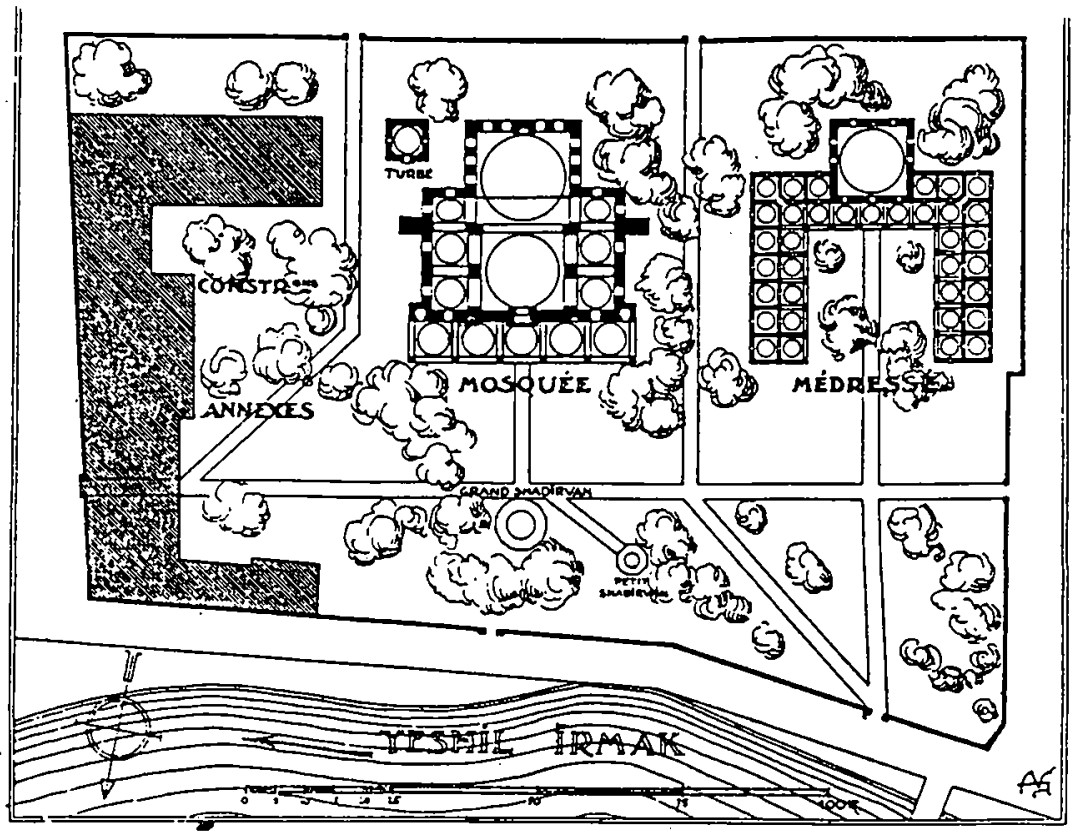

Şekil 1. Amasya II. Bayezid Külliyesi'nin vaziyet plânı (A. Gabriel'den) 


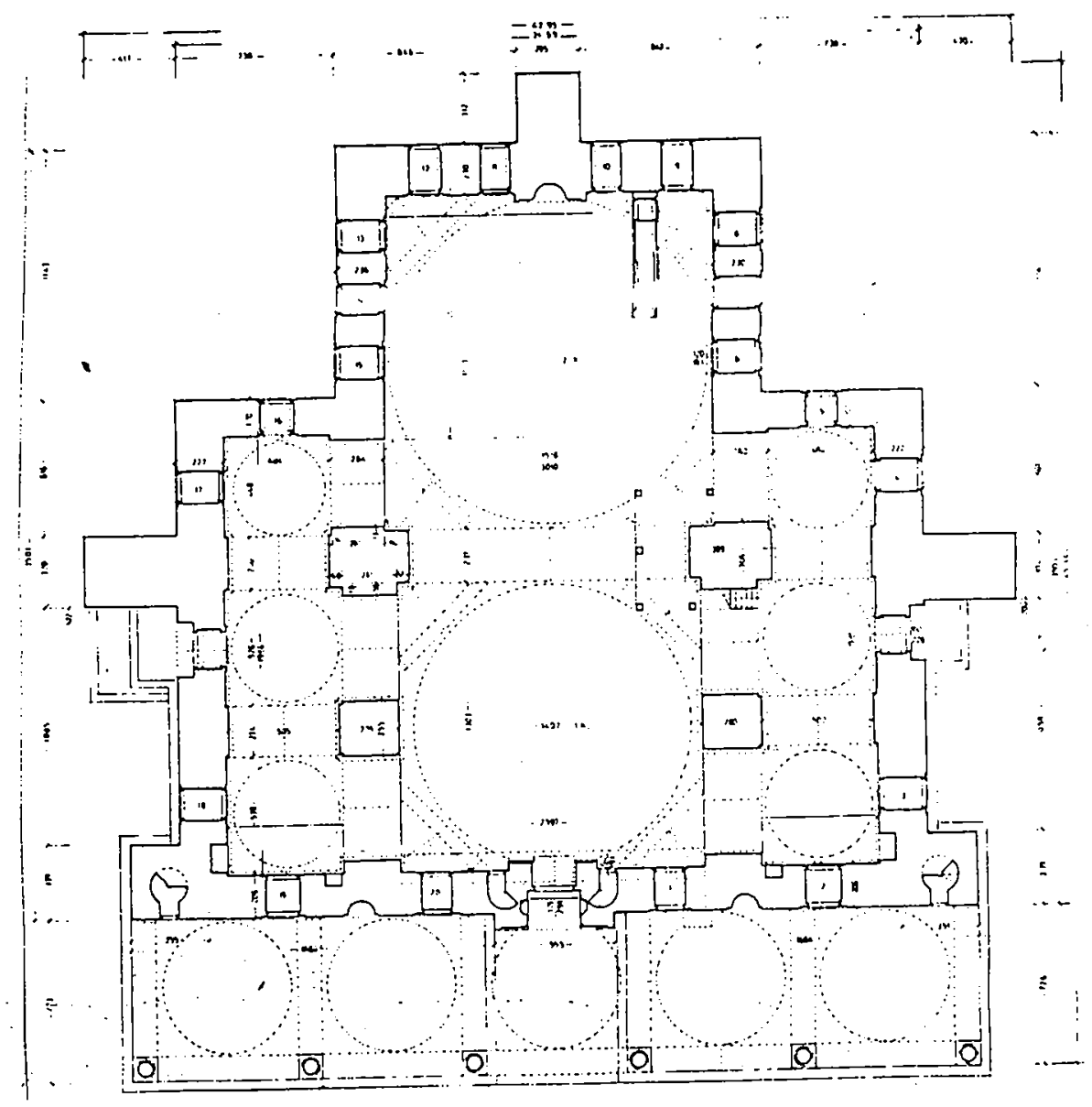

Şekil 2. Amasya II. Bayezid Câmii'nin plânı (İ. Aydın Yüksel'den) 


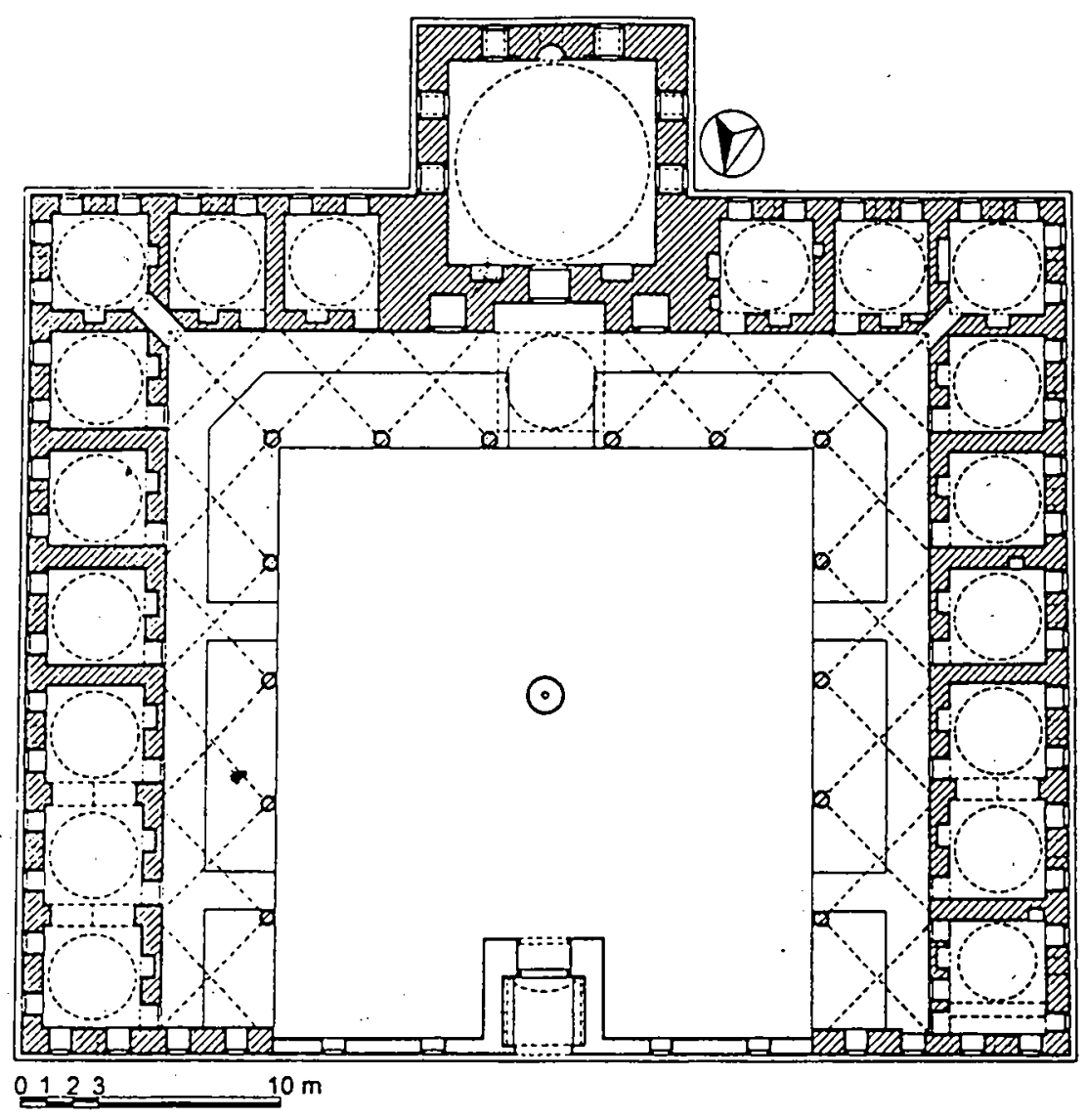

Şekil 3. Amasya Il. Bayezid Medresesi'nin plânı (Y. Demiralp'den) 


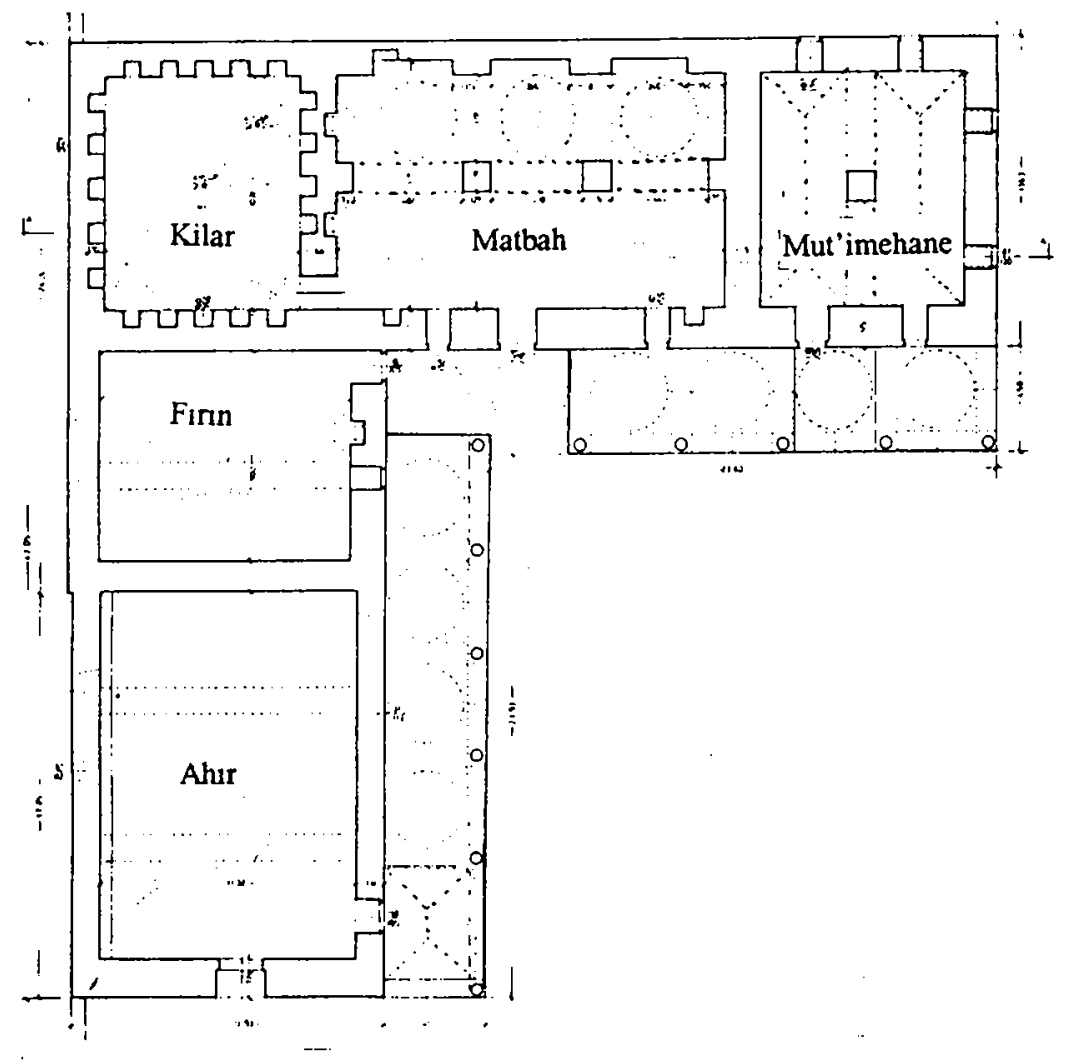

Şckil 4. Amasya II. Bayezid İmareti plânı (í. Aydın Yüksel'den) 


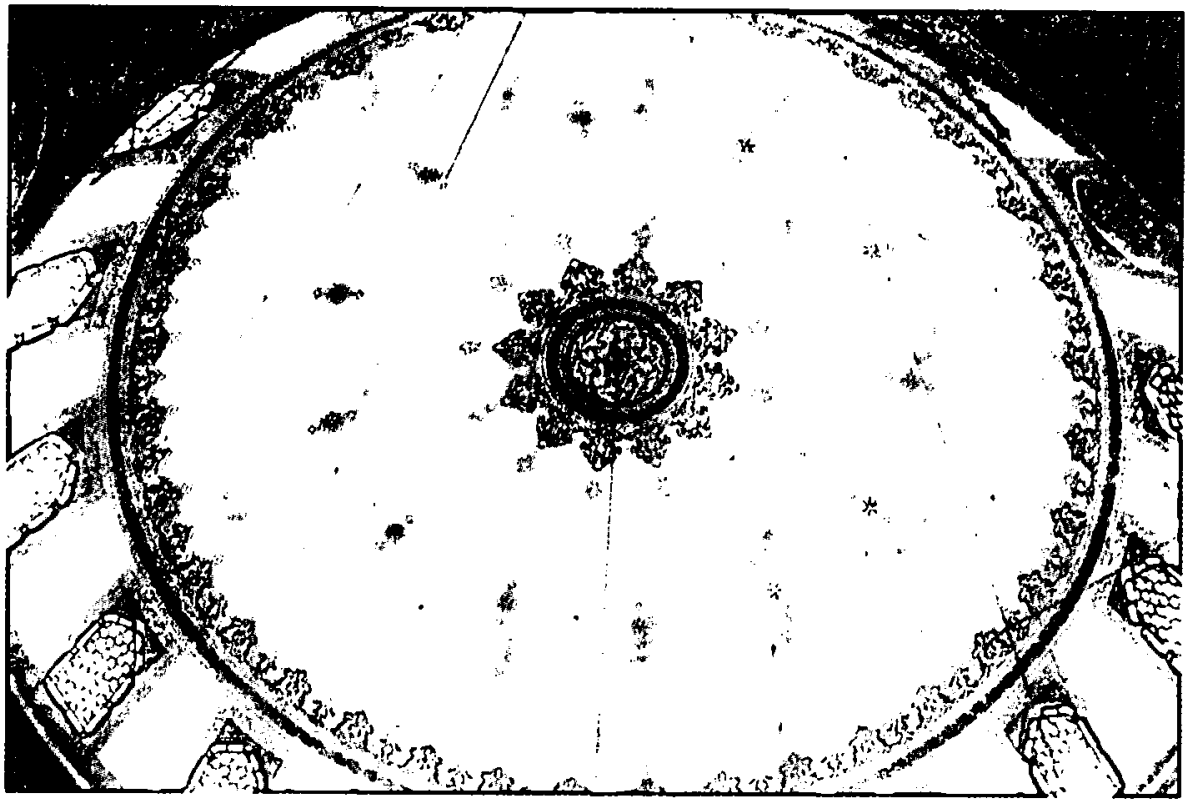

Fotoğraf 1- Amasya II. Bayezid Câmii'nin mihrap önü mekânını örten kubbesi.

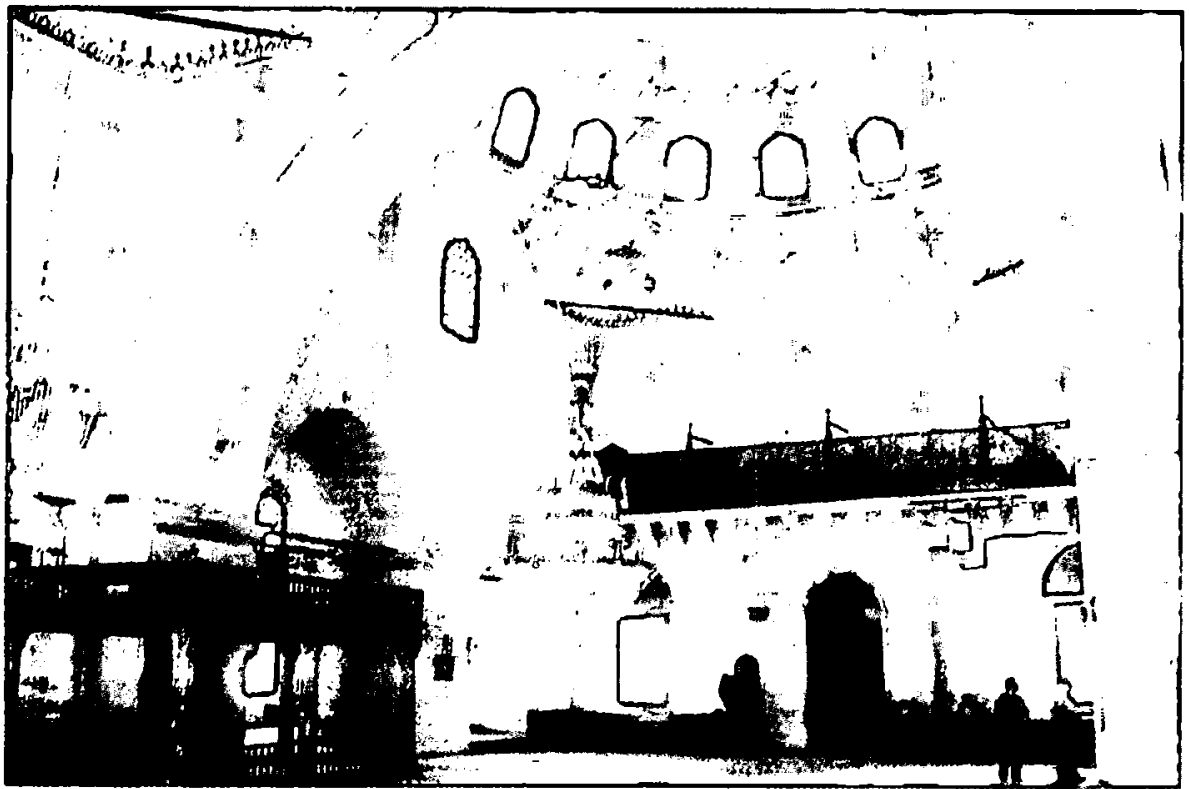

Fotoğraf 2- Amasya II. Bayezid Câmii'nin ortasındaki kemcr ve kuzey duvarındaki mahfil. 


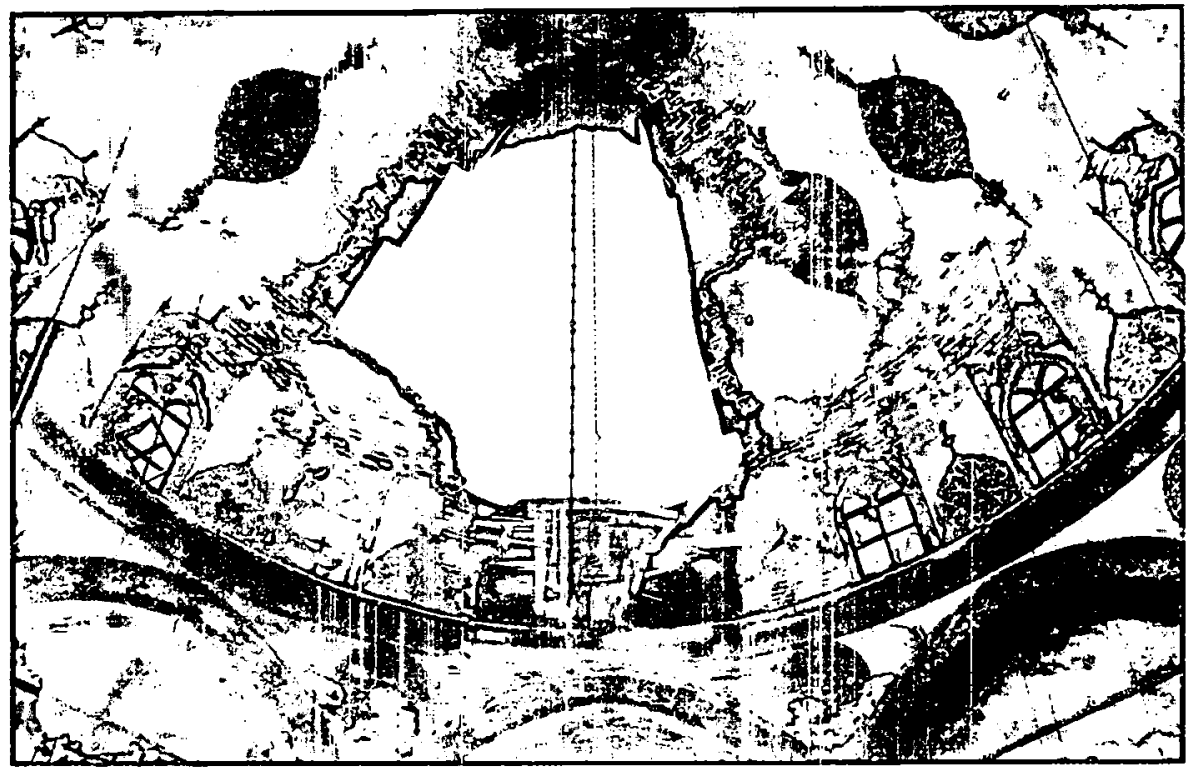

Fotoğraf 3- Amasya II. Bayezid Câmii ön kubbesinin 1952 yılından önceki durumu ve süslemeleri (VGMA'den)

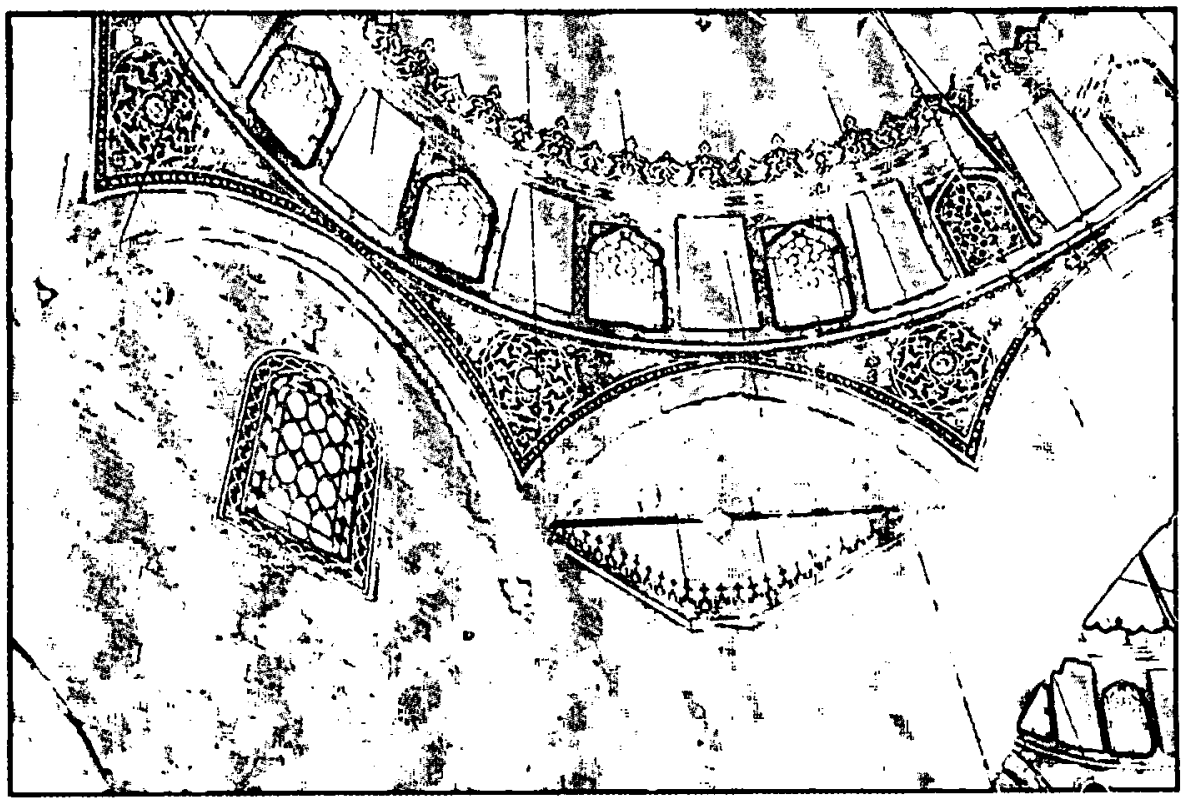

Fotoğraf 4- Amasya II. Bayezid Câmii'nin arka kubbesindeki geçiş unsuru ve kubbenin etrafındaki 1952 yılından sonra yapılan süslemcler 


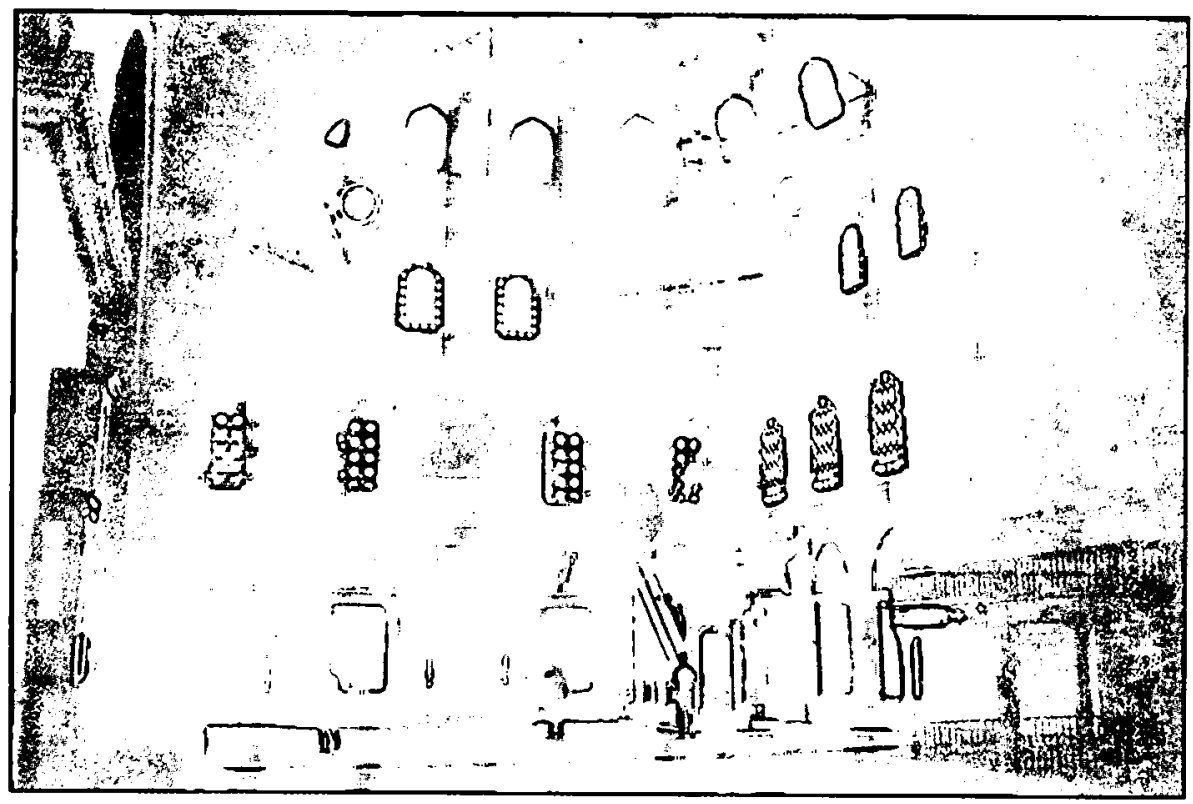

Fotoğraf 5- Amasya II. Bayezid Câmii'nin içinden bir görünüm

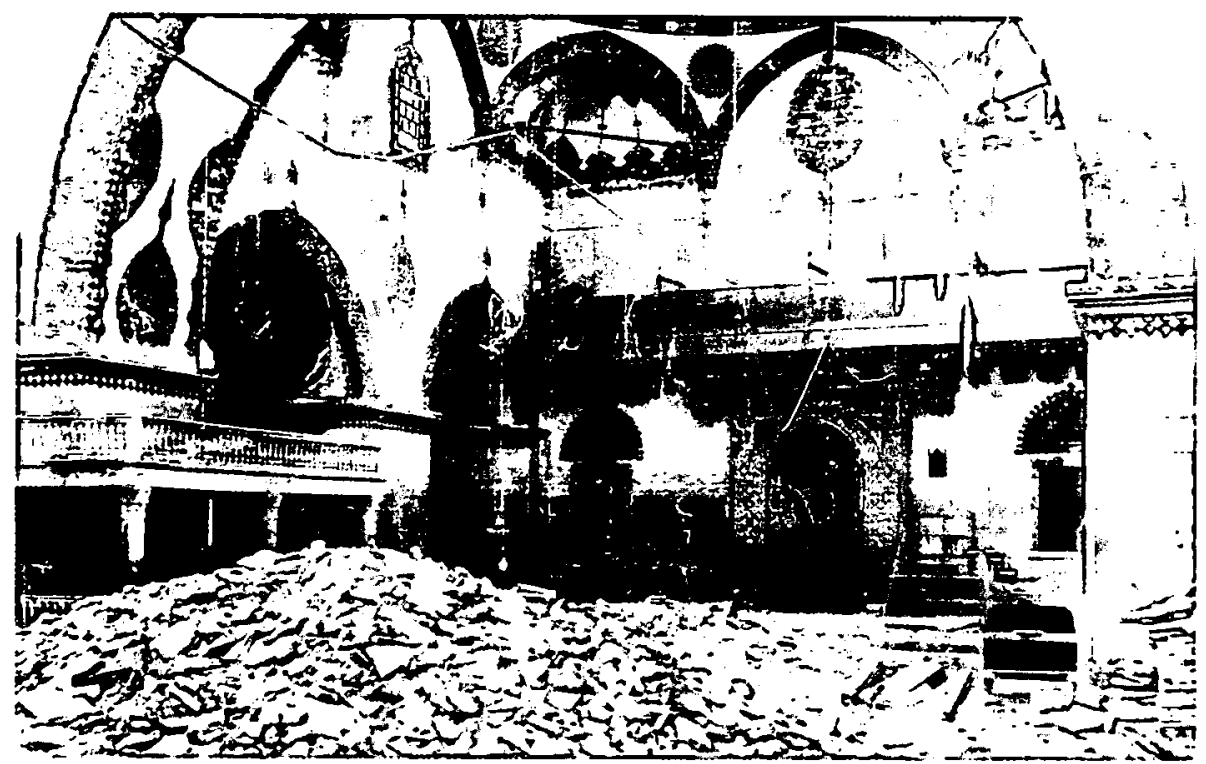

Fotoğraf 6- Amasya II. Bayezid Câmii'nin arka mekânındaki kalem işlcrinin 1952 yılından önceki durumu (VGMA'den) 


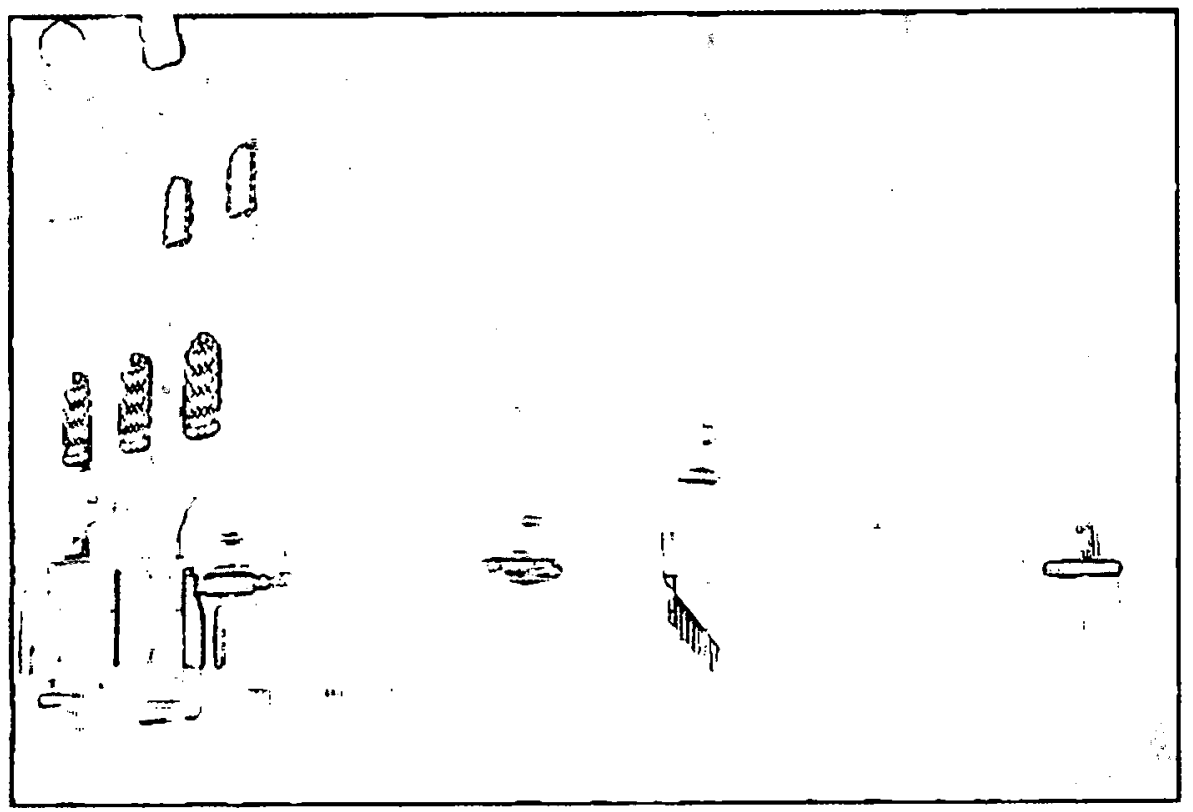

Fotoğraf 7- Amasya II. Bayezid Câmii’nin müezzin mahfili.

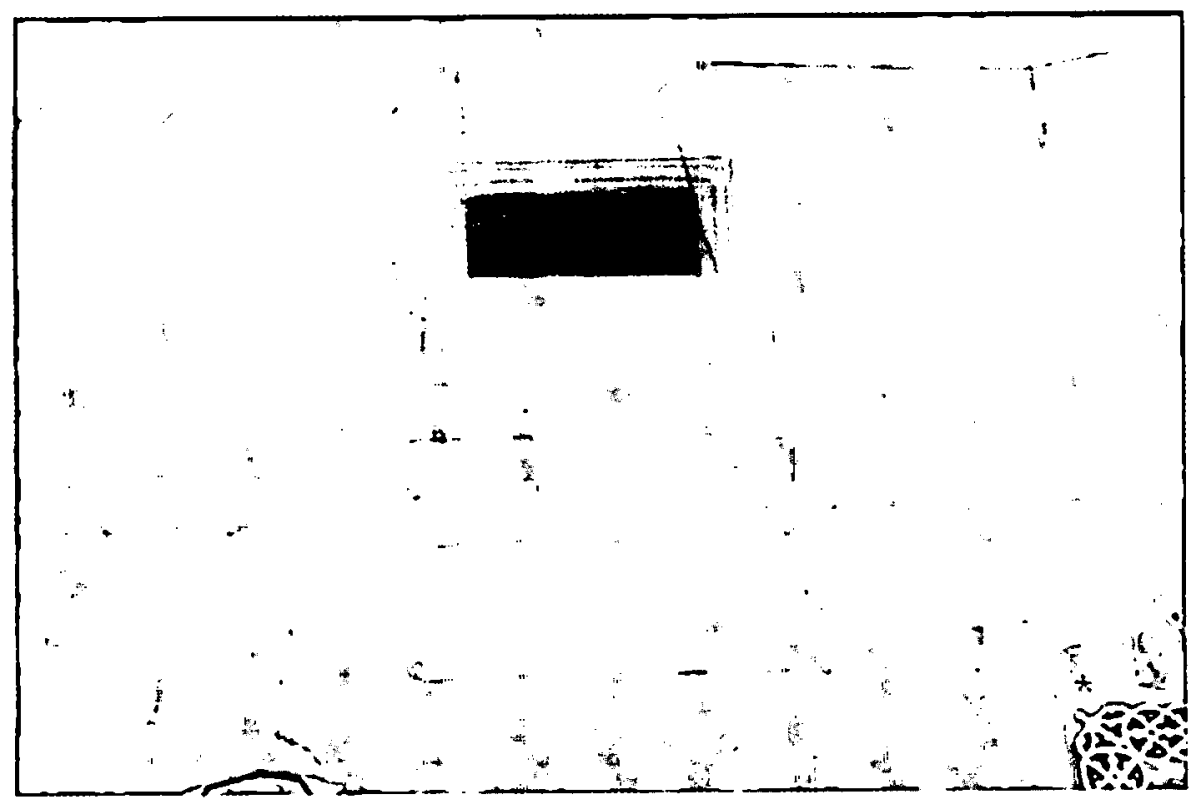

Fotoğraf 8- Amasya II. Bayezid Câmii taçkapısının batısındaki pencerenin üstündeki mükebbire 


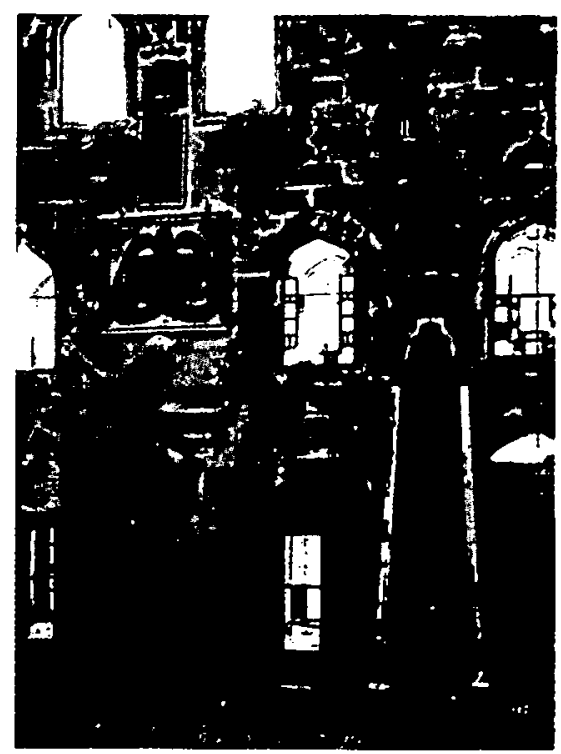

Fotoğraf 9- Amasya II. Bayezid Câmii mihrap ve minberinin 1952 yılından önceki durumu (VGMA'den).
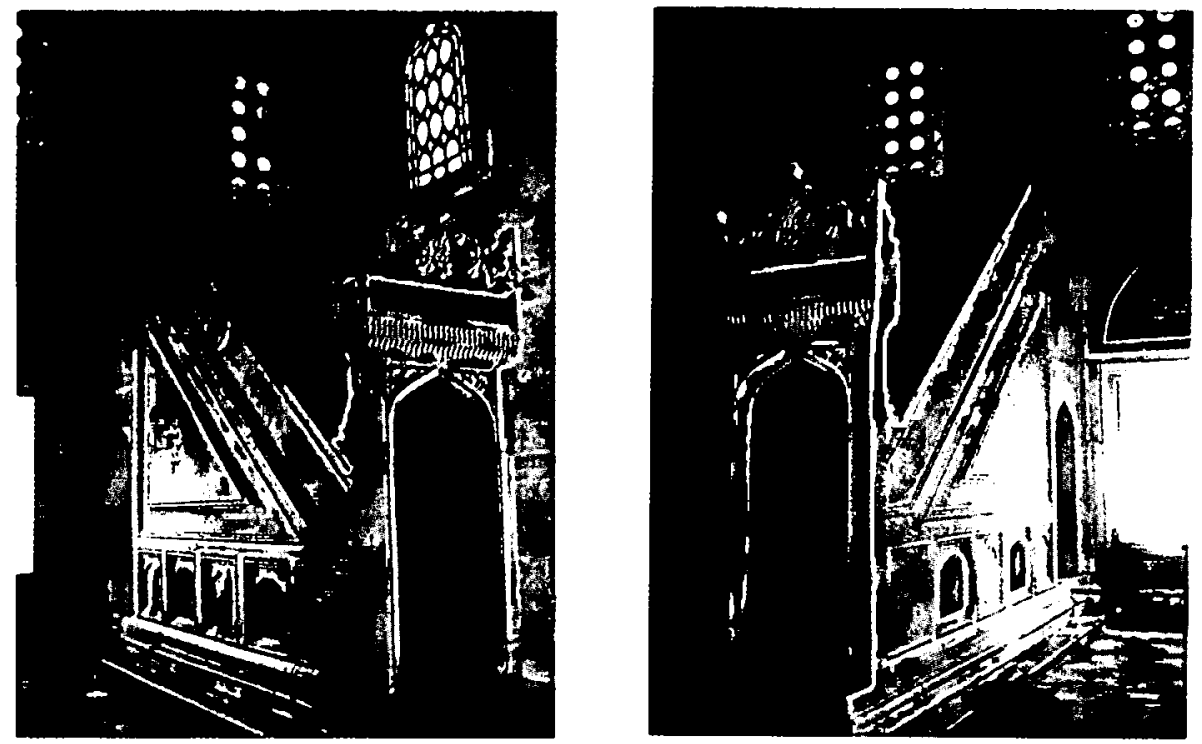

Fotoğraf 10- Amasya II. Bayczid Câmii'nin minberi. 

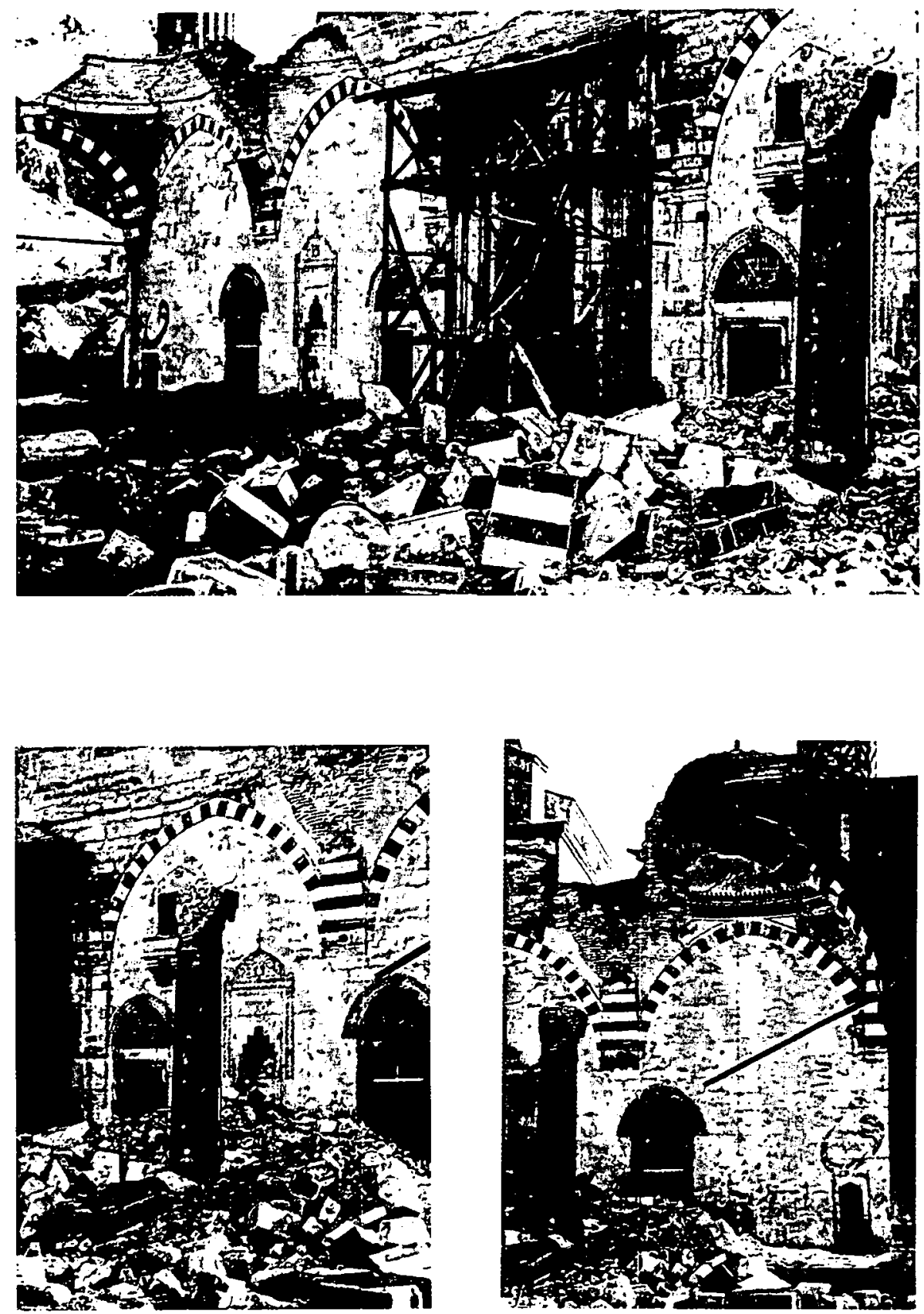

Fotoğraf 11- Amasya II. Bayezid Câmii son cemaat yerinin 1952 yılından önceki durumu (VGMA'den) 


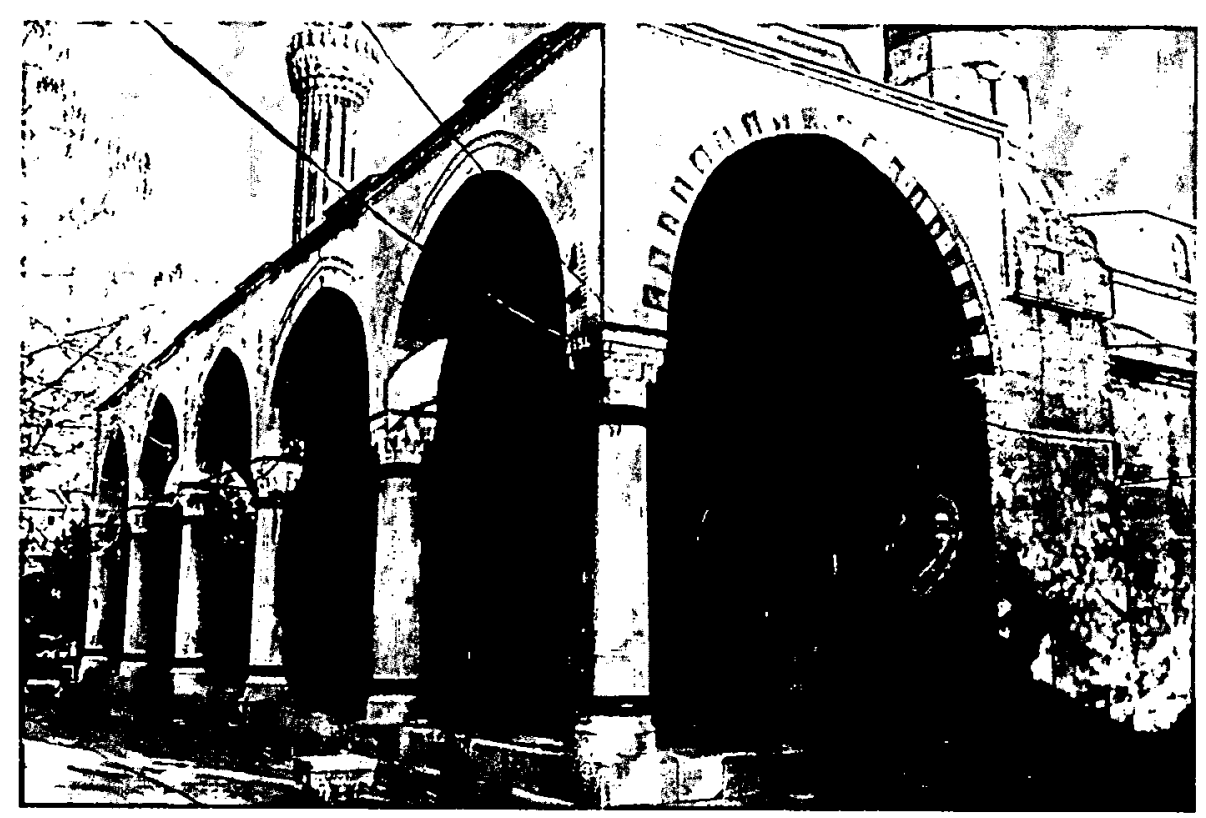

Fotoğraf 12- Amasya II. Bayezid Câmii 'nin son cemaat yeri.

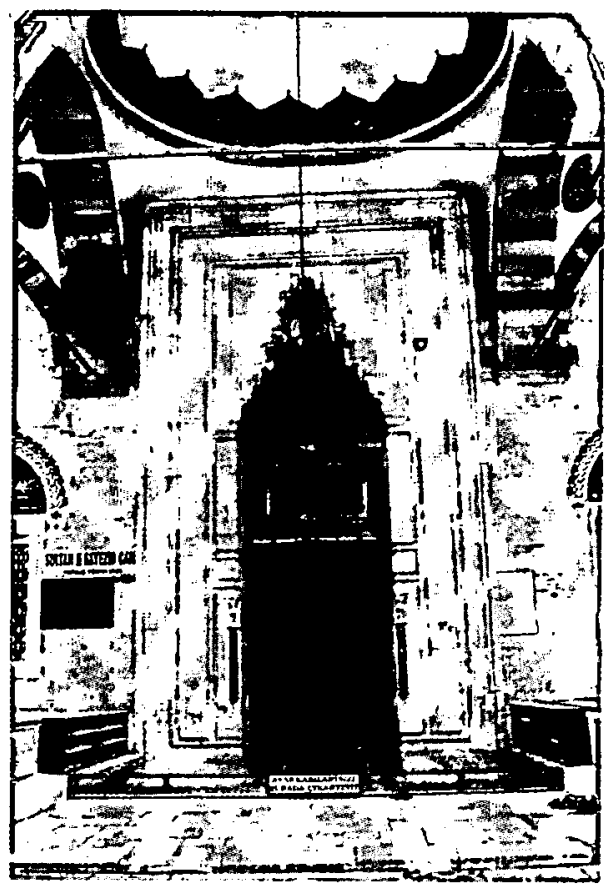

Fotoğraf 13- Amasya II. Bayezid Câmii 'nin taçkapısı. 


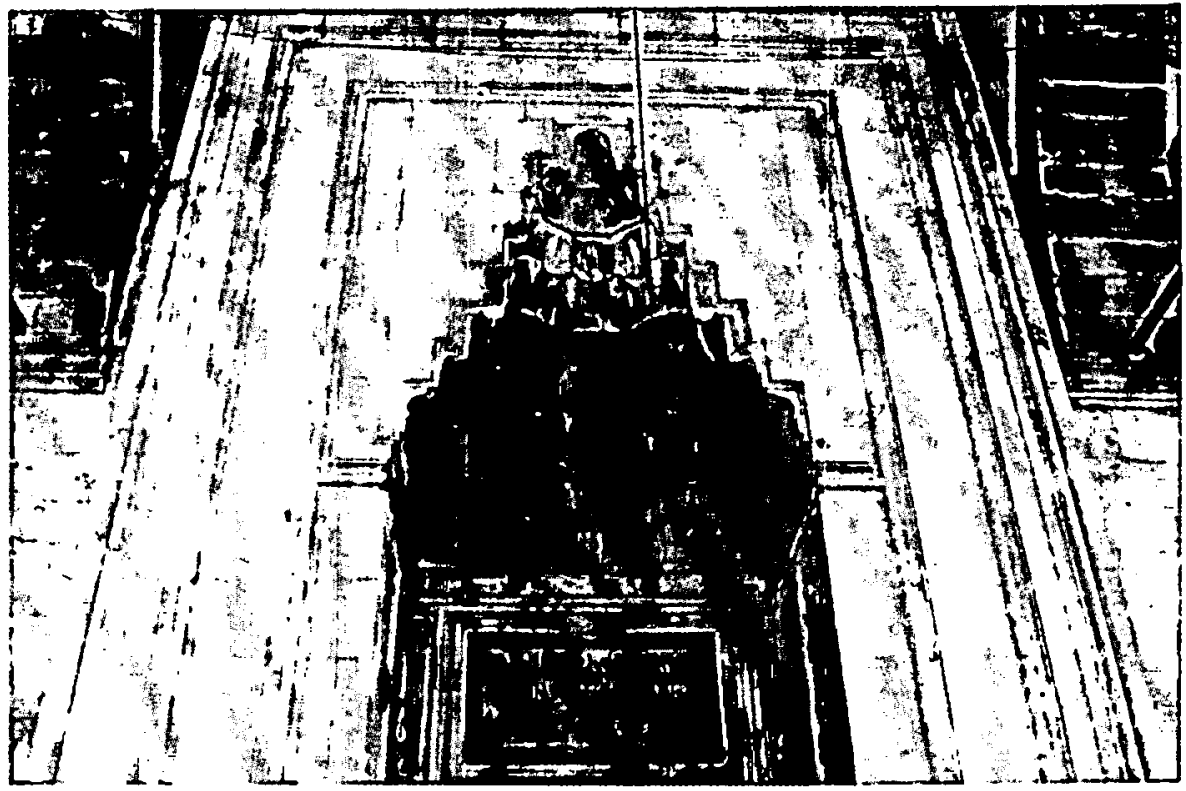

Fotoğraf 14- Amasya II. Bayezid Câmii ‘nin taçkapısı kavsarasındaki mukarnaslar.
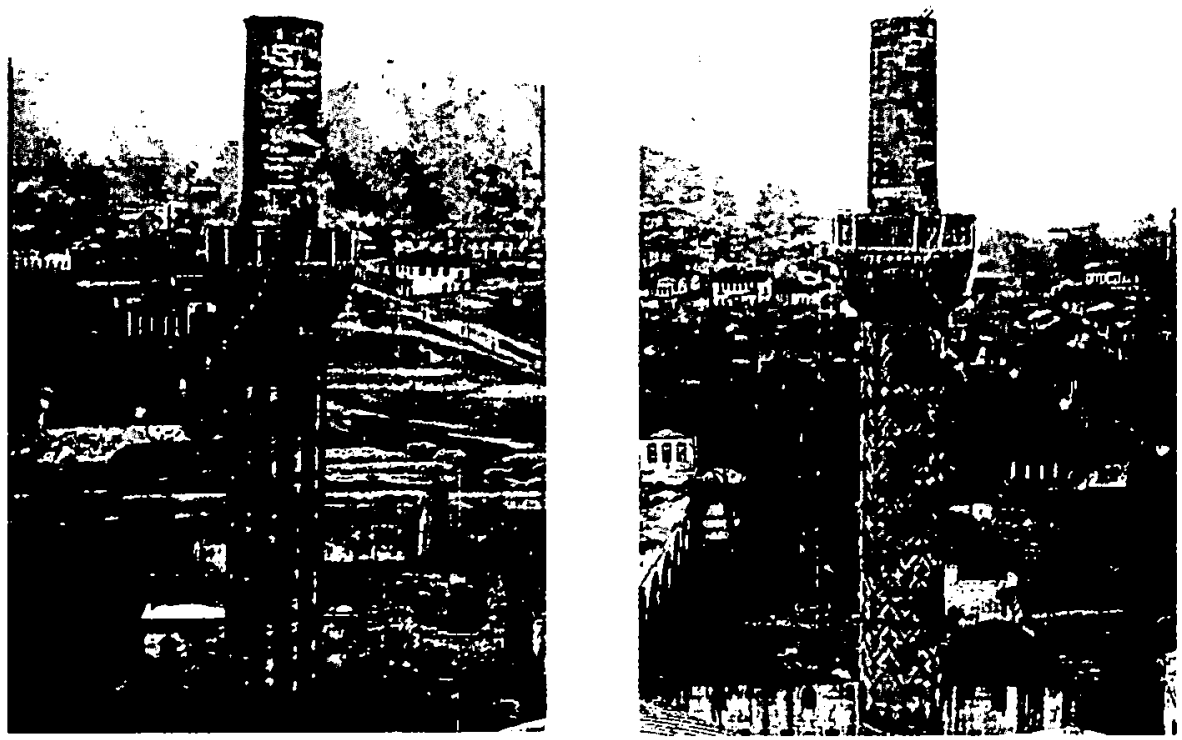

Fotoğraf 15- Amasya II. Bayezid Câmii 'nin minarelerinin 1952 yılından önceki durumlan (VGMA'den). 


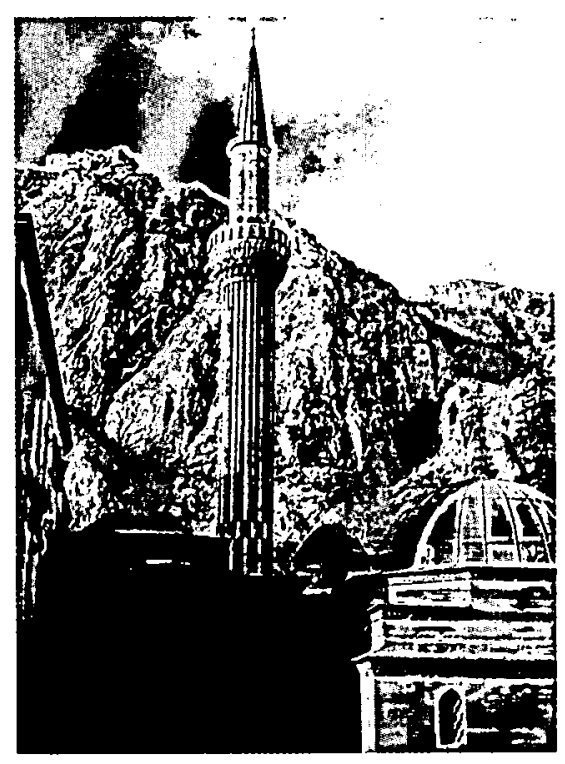

Fotoğraf 16- Amasya II. Bayezid Câmii 'nin kuzeydoğu köşesindeki minare.

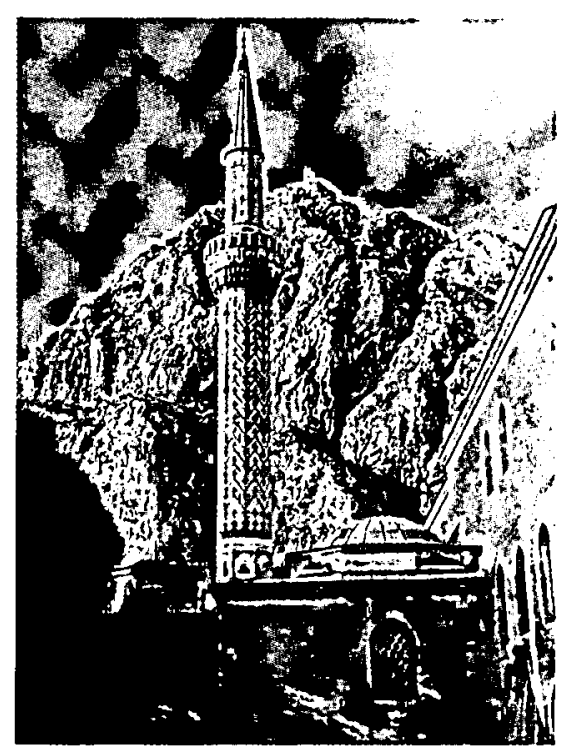

Fotoğraf 17- Amasya II. Bayezid Câmii 'nin kuzeybatı köşesindeki minare. 
Fotoğraf 18- Amasya II. Bayezid Câmii 'nin kuzeyindeki şadırvan.

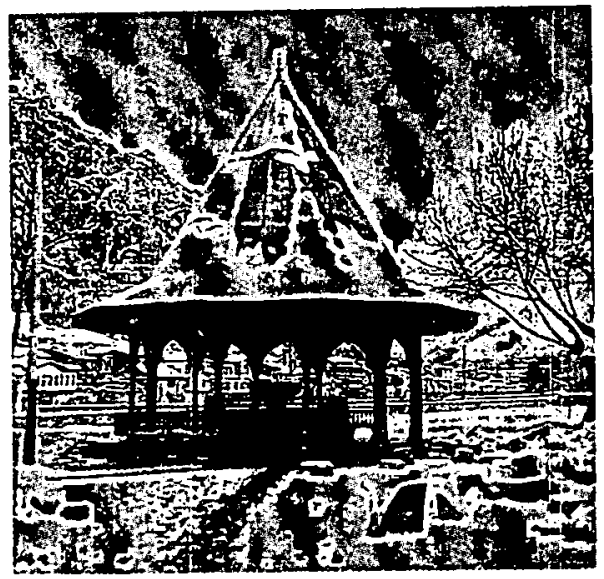

a) Şadırvanın 1952 yılından önceki durumu (VGMA'den)

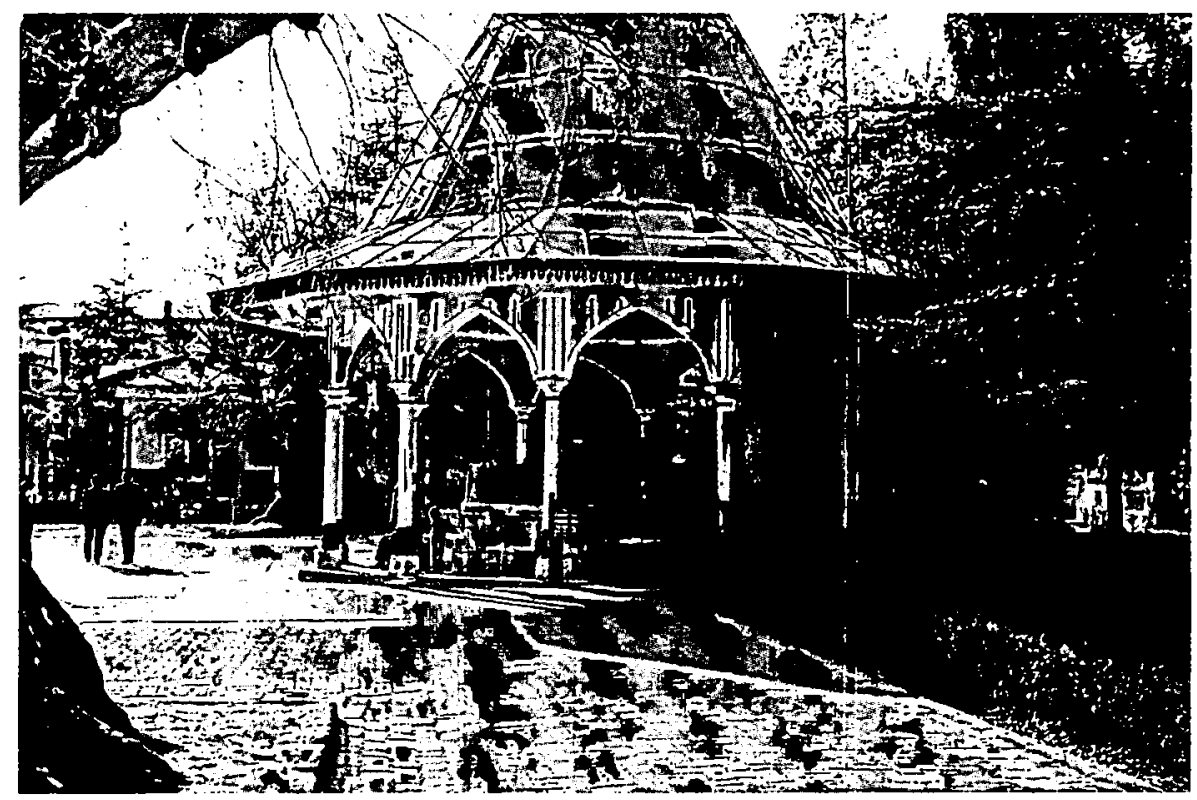

b) Şadırvanın bugünkü durumu. 

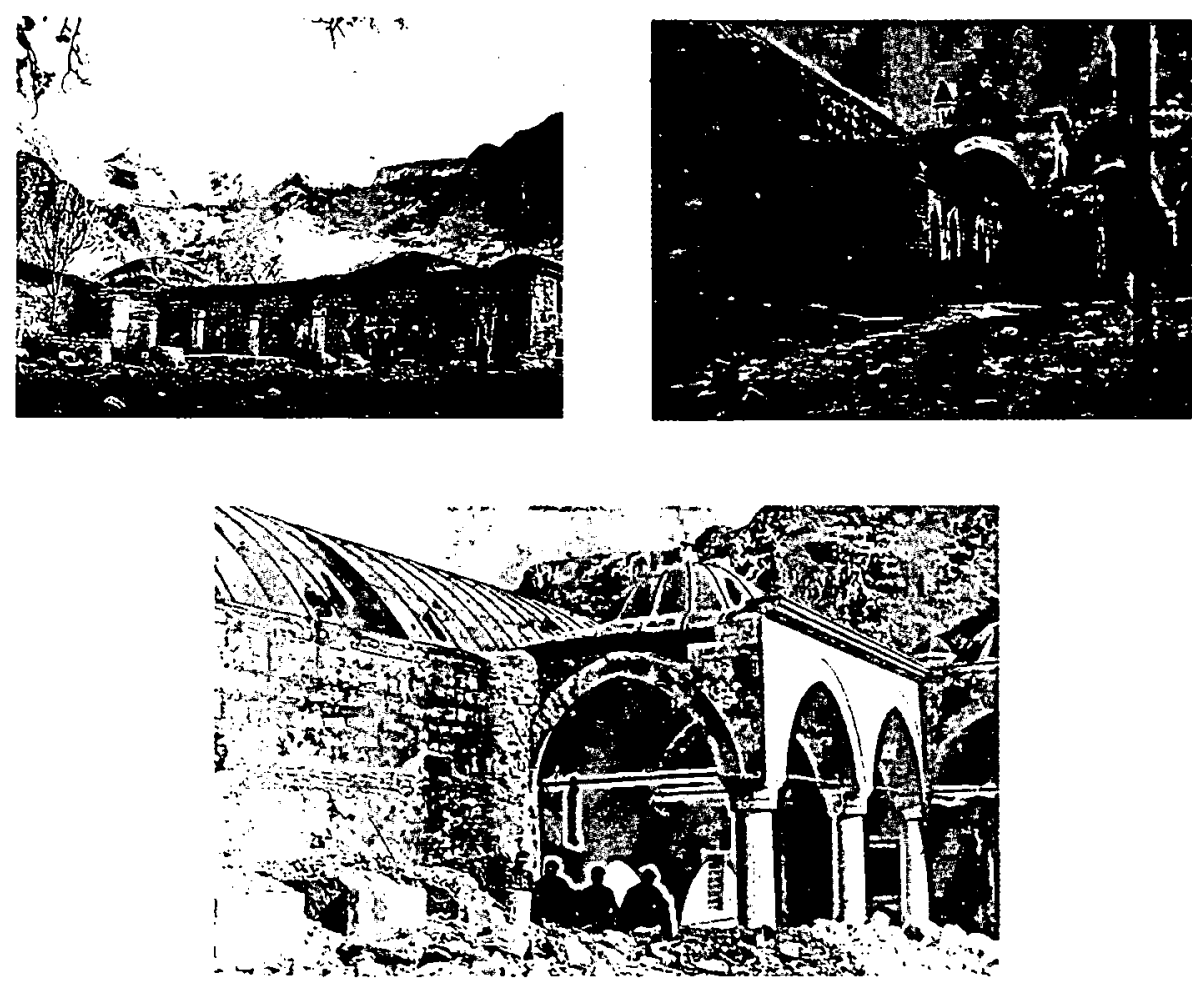

Fotoğraf 19- Amasya II. Bayczid İmarcti revakının 1952 yılından önceki durumu (VGMA'den)

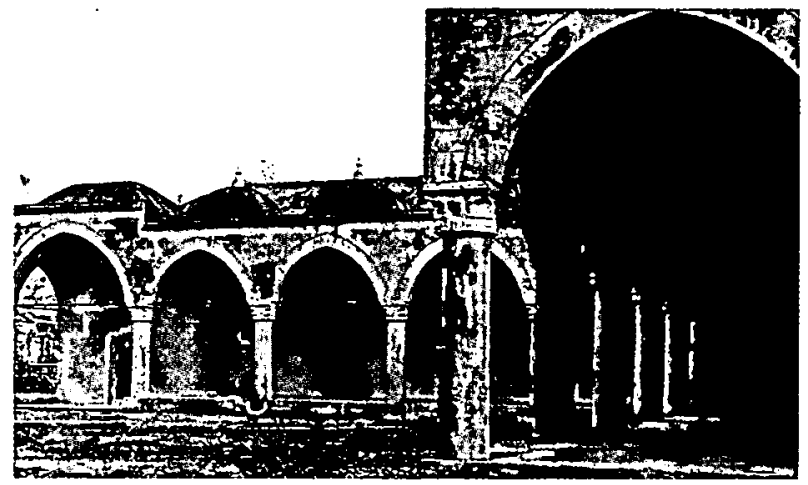

Fotoğraf 20- Amasya II. Bayczid Imareti revakının 1965 yılından sonraki durumu (VGMA'den) 


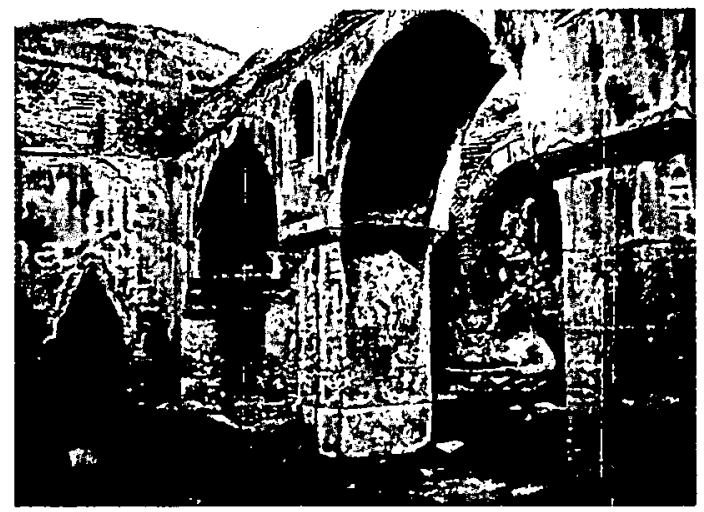

Fotoğraf 21 - Amasya II. Bayezid İmareti matbahının 1952 yılından önceki durumu (VGMA'den)

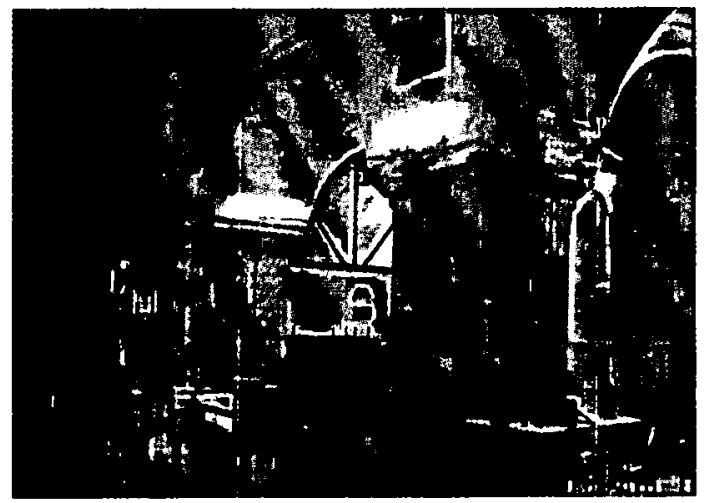

Fotoğraf 22- Amasya II. Bayezid Imareti matbahının içinden detay.

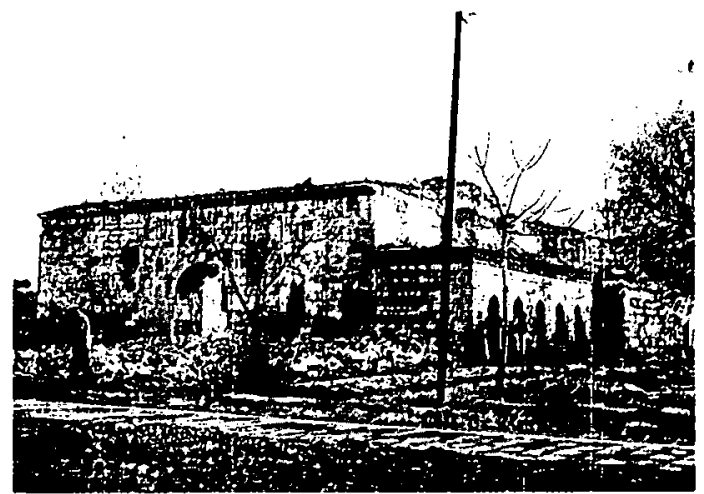

Fotoğraf 23- Amasya II. Bayezid İmareti ahırının kuzey cephesi ve batısındaki revakın yerine yapılan helâların 1952 yılından önceki durumu (VGMA'den) 


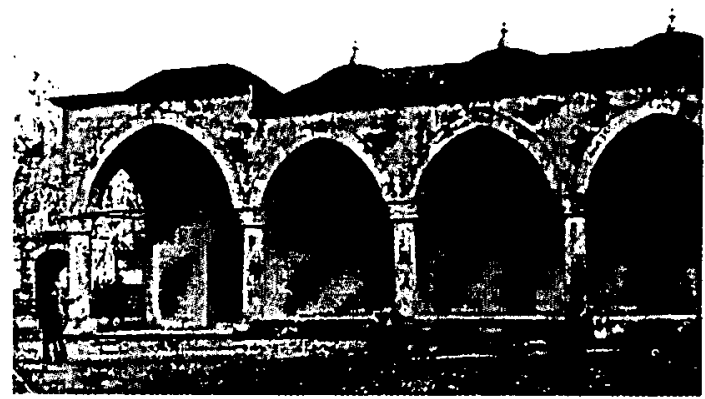

Fotoğraf 24- Amasya II. Bayezid İmarcti ahır revakının 1965 yılındaki durumu (VGMA'den)

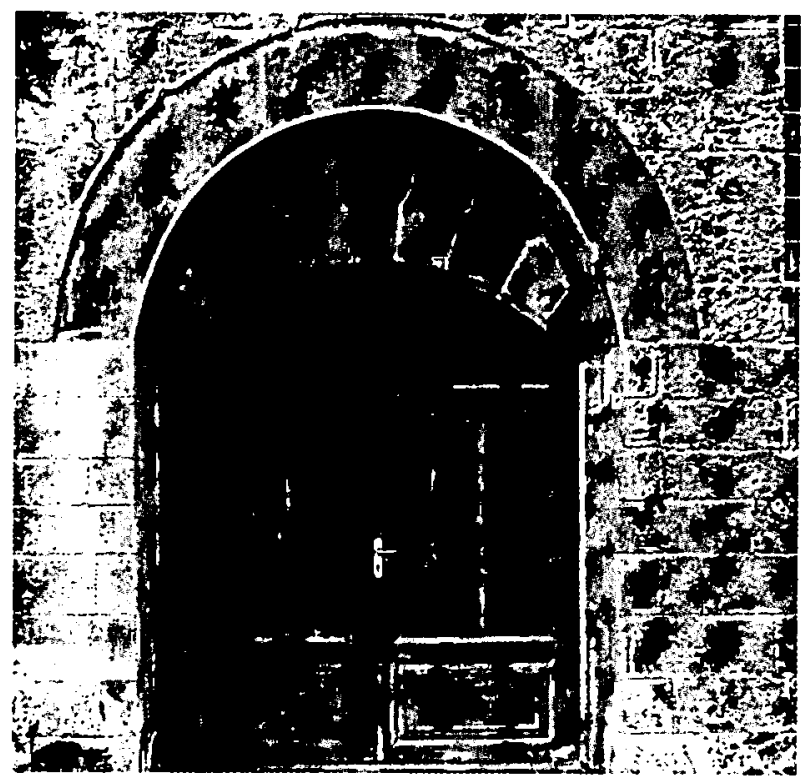

Fotoğraf 25- Amasya II. Bayezid İmareti ahırının kuzcy kapısı.

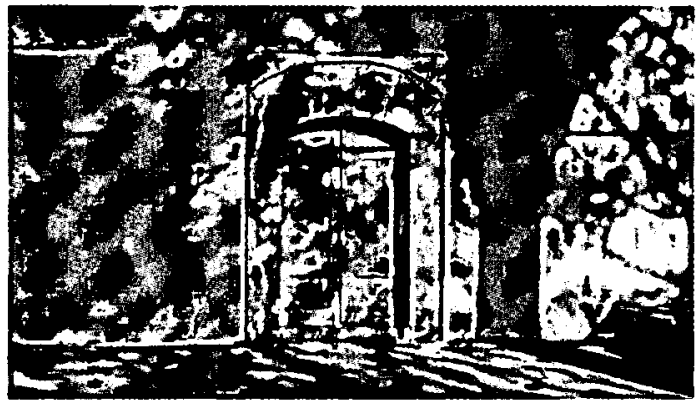

Fotoğraf 26- Amasya II Bayezid İmareti ahırının kuzeybatı kapısı. 


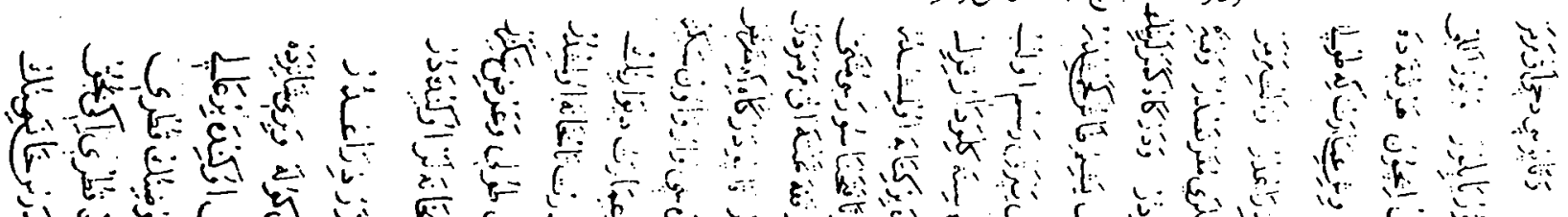

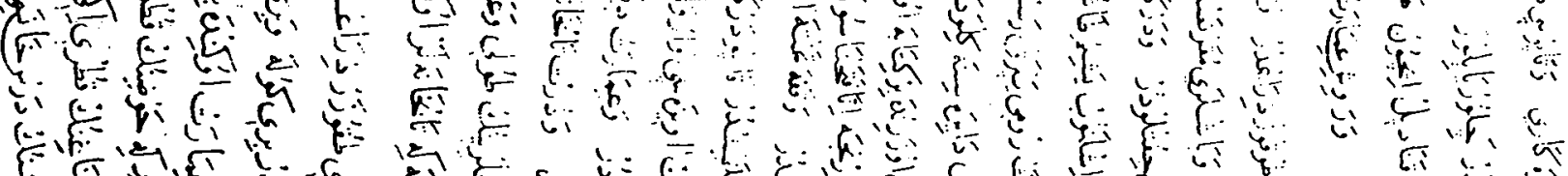

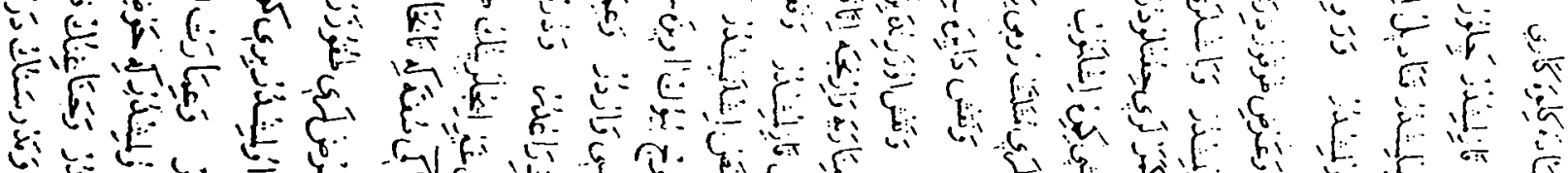
$5 . c \%$ क

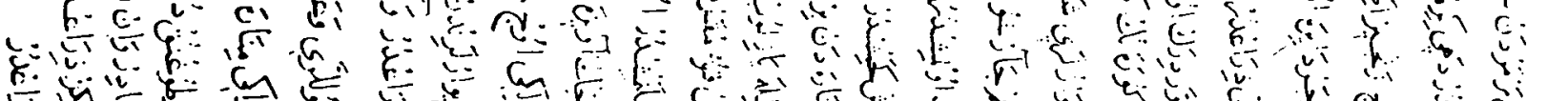

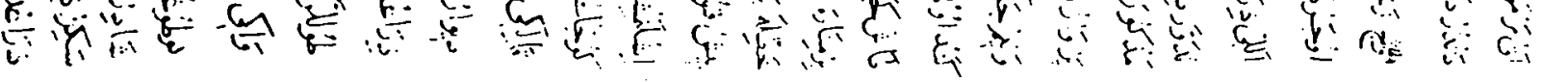

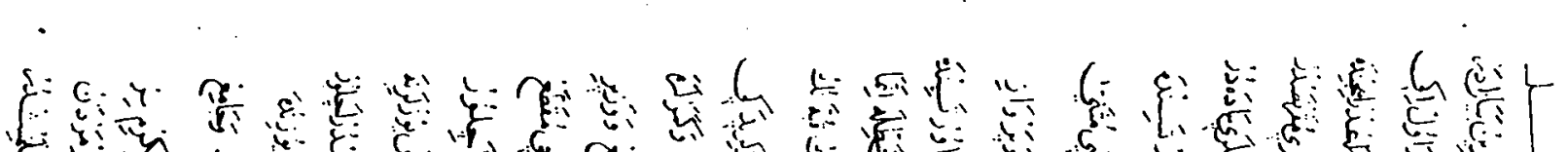

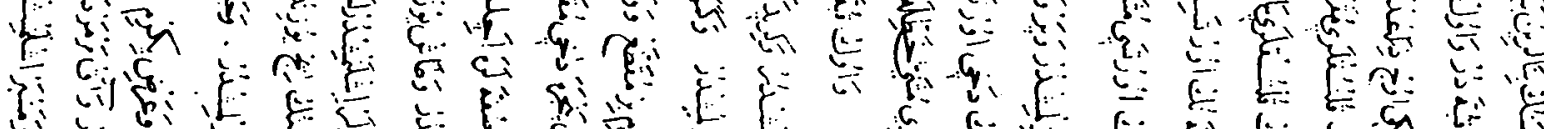

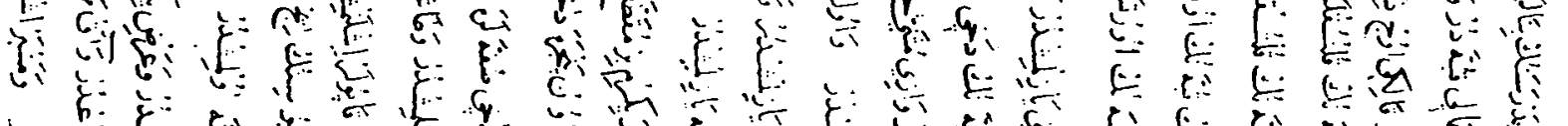

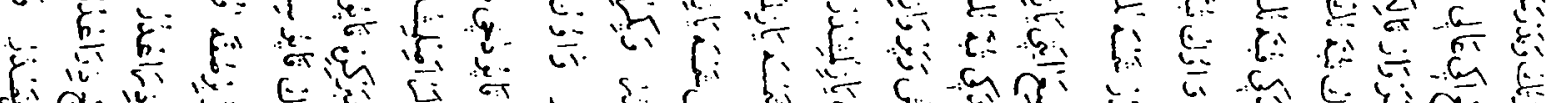
b

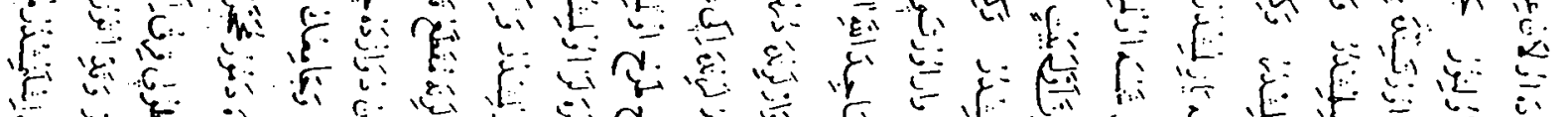

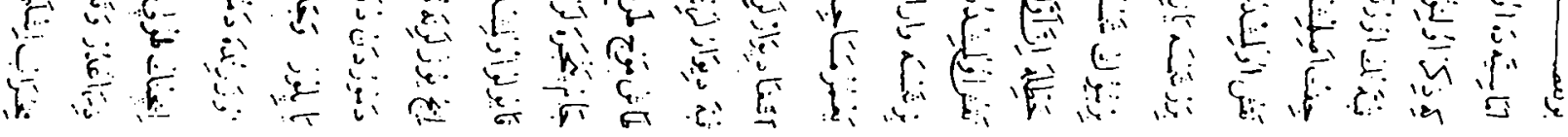




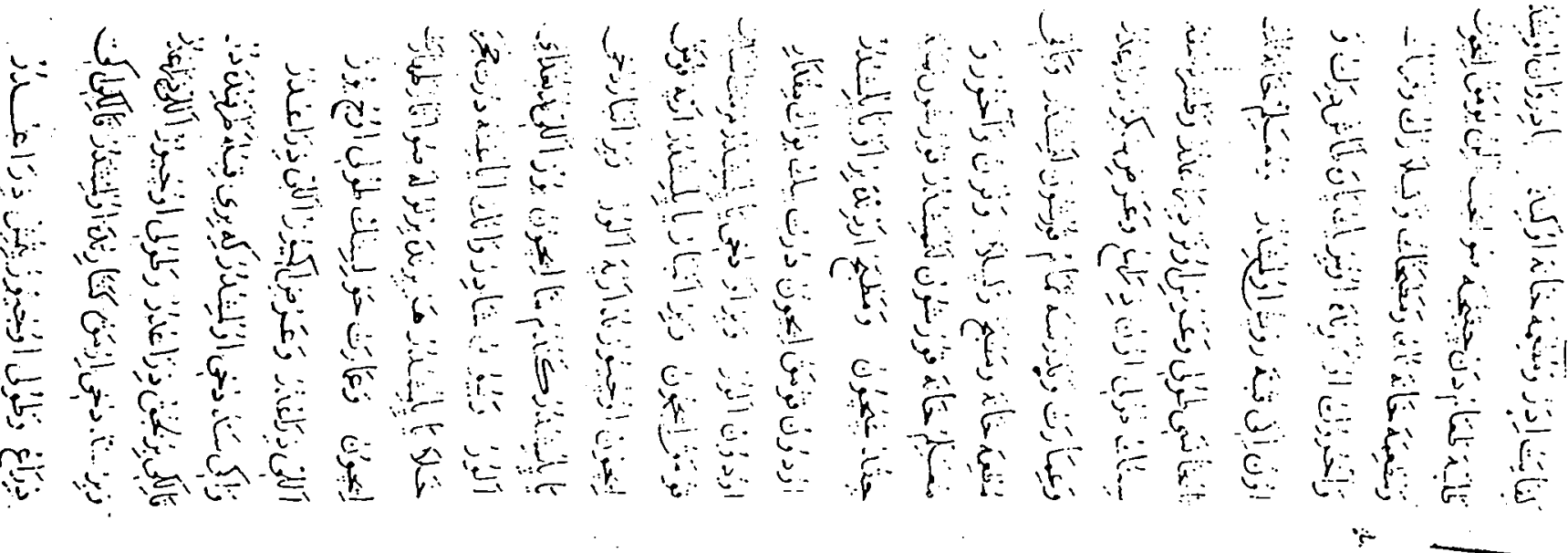

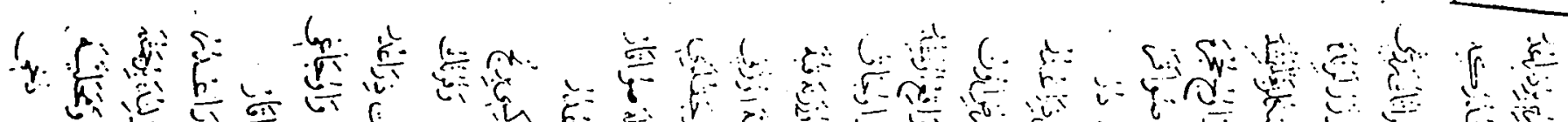

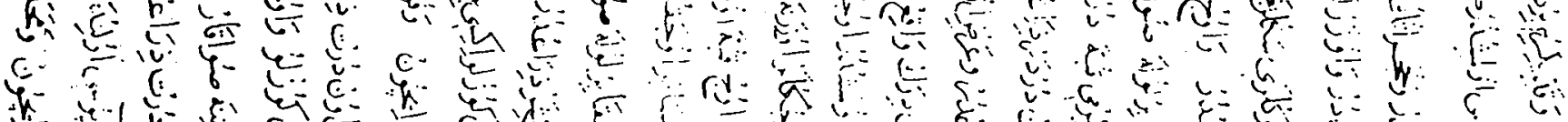
द. c)

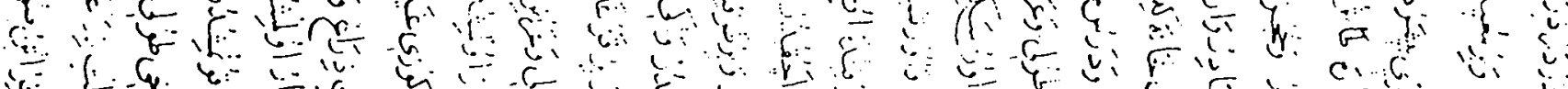
C

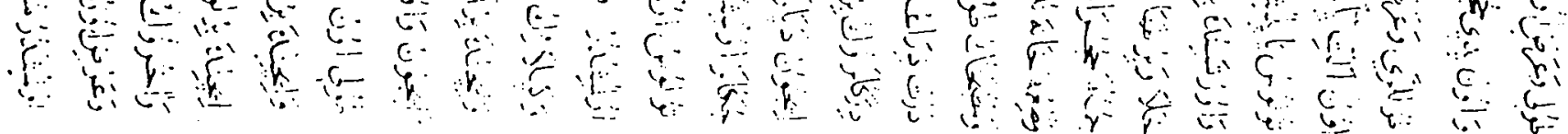




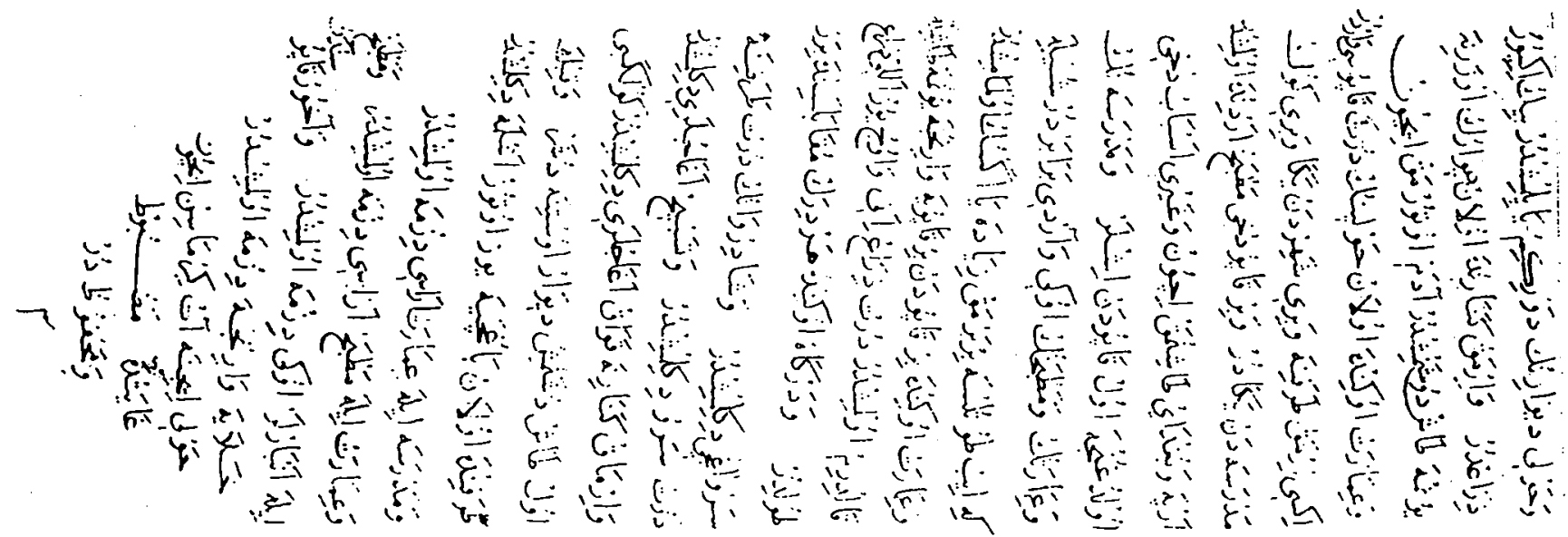

